\title{
شعرية التشكيل البصري وانفتاح الدلالة
}

أ. أ.د عبد النـاصـر هلال

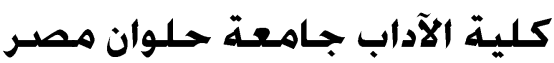

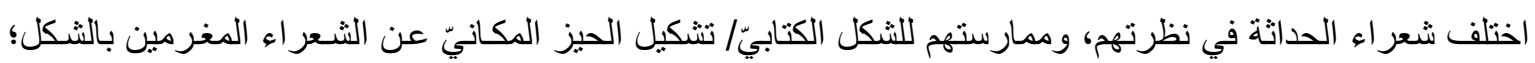

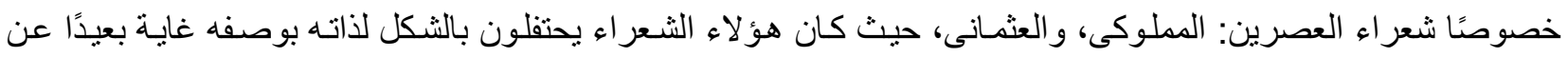

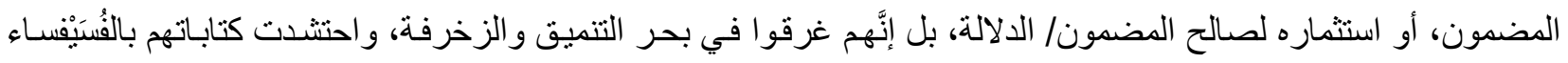

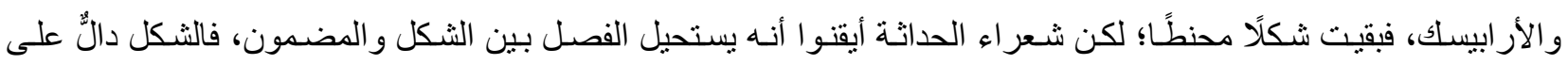

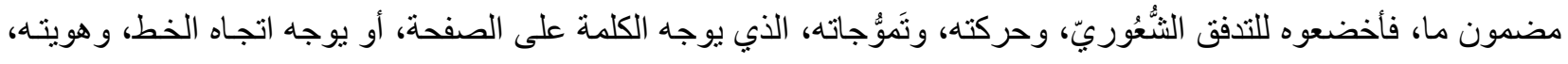

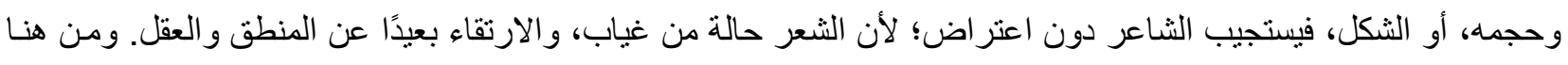

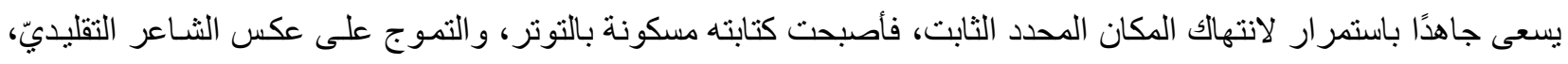

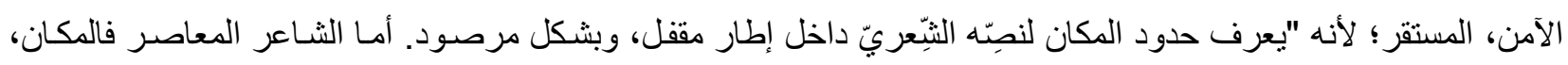

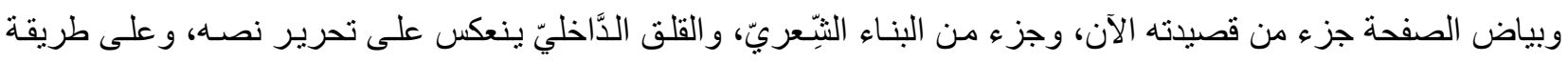

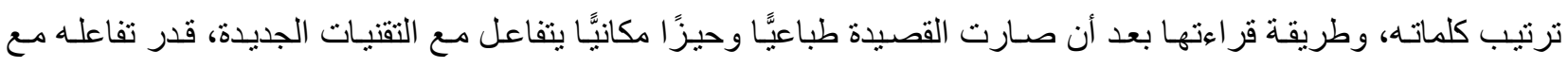

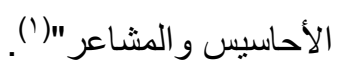

لقد تغيرت رؤية العالم عند الثـاعر الجديد، واختلفت قر اءته للأشياء، وتباينت حركته الوجدانية؛ ممـا استدعى اختلافًا

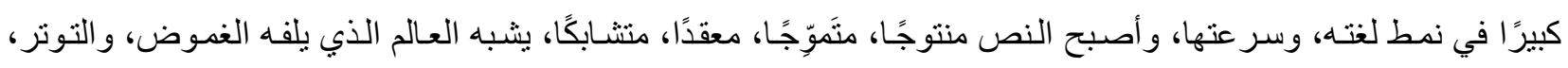

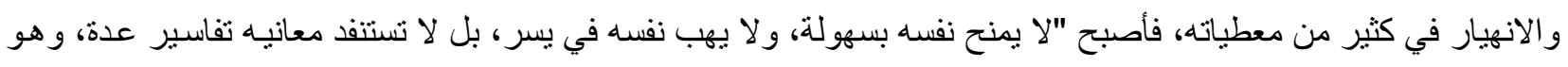

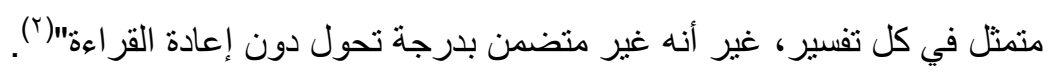

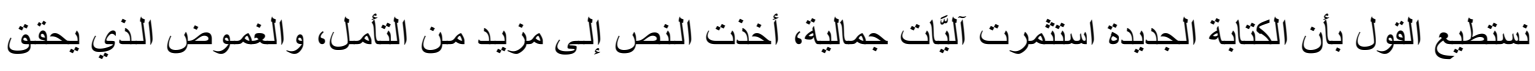

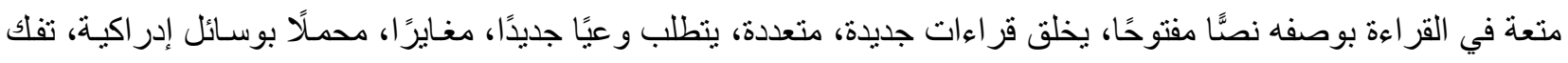

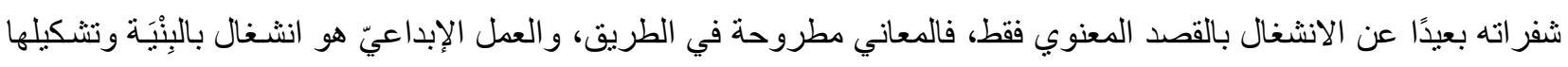

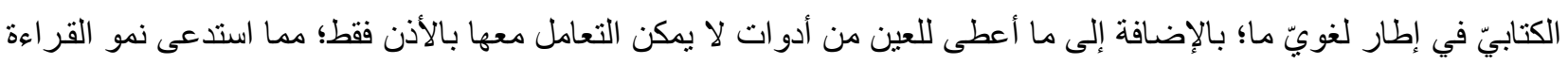

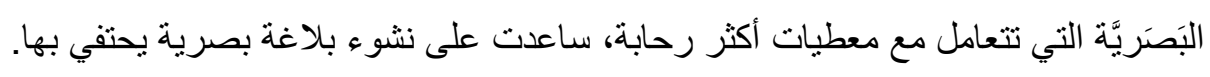

إذا كان الالتفات النصيّ - فيما سبق - قد تحقَّق عبر آليَّات بنائية ـ اعتمدت على السباق التكوينيّ للغنة في مظهرهـا

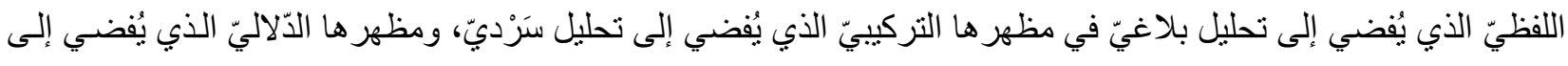

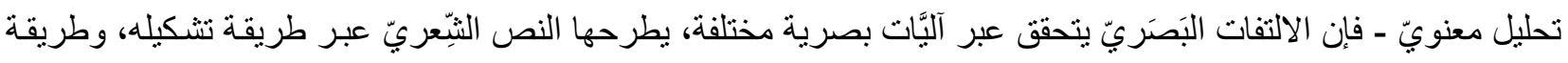

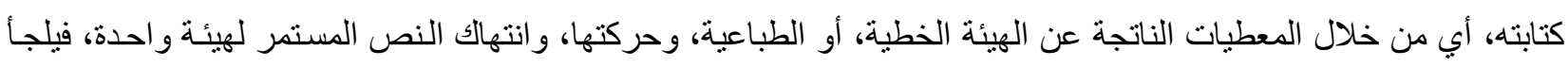

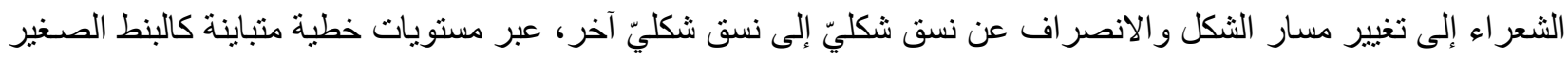
= الأبيض، و البنط الكبير، ذو السمك = الأسود، وبياض الصفحة يُسمى الفراغ، هذه المستويات الثناثنة: الأبيض، الأسود،

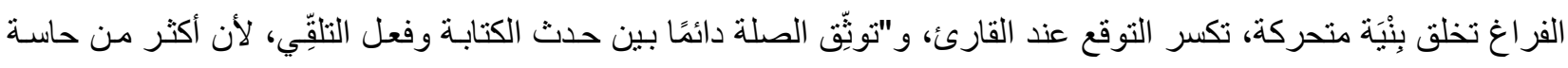

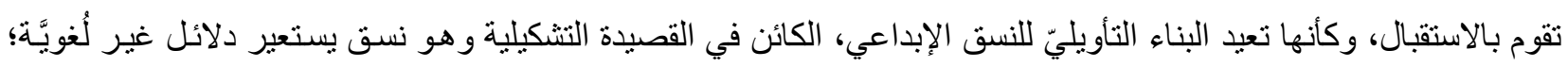




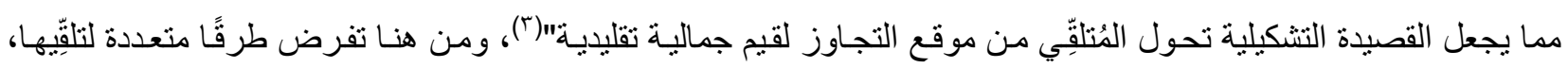

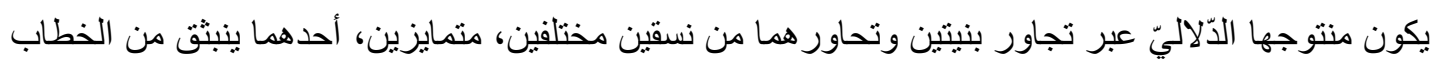

الالتفات البصري

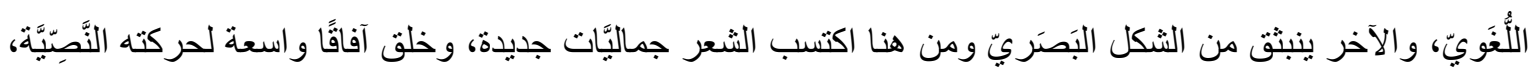

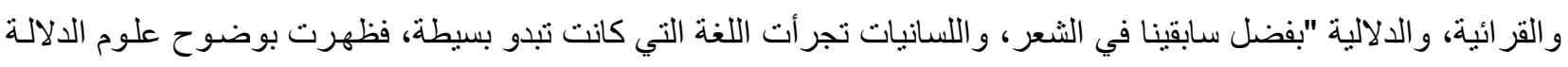

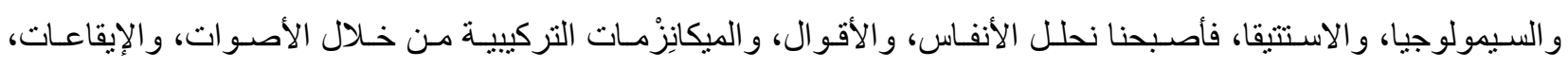

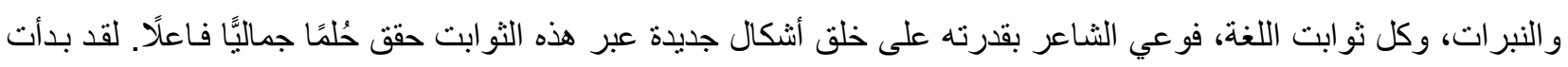

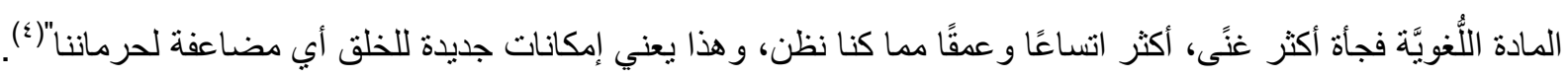
لقد أصبح الثاعر الجديد لاعبًا ماهرًا، ينظر في كل الأشياء بدقة، لقد تخلص من فكرة الاستجابة للداخل، و التدفق

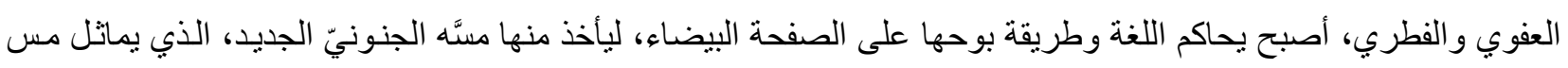

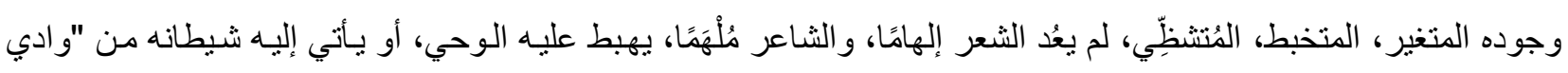

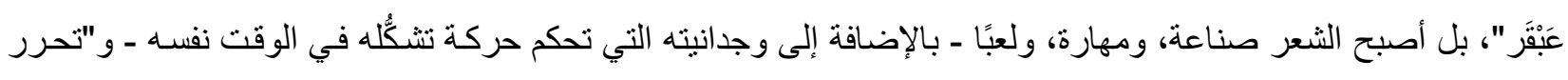

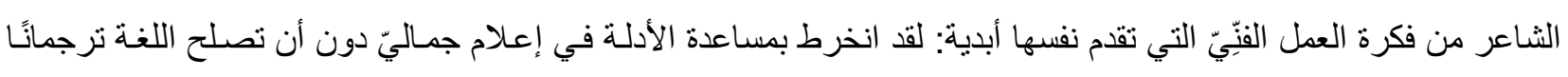

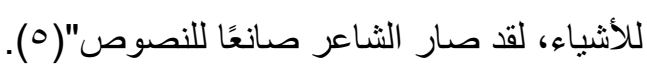

\section{هن النص إلى الذطاب ـ آليَّات الالتفات البَصتريّ البَّهبِيّي}

تعددت آلََّّات الالتفات البَصَريّ النَِّيّيّ في الشعر المعاصر ، متحققه في جزء من قصيدة أو قصيدة كاملة:

\section{الالتفات عبر السواد والبياض}

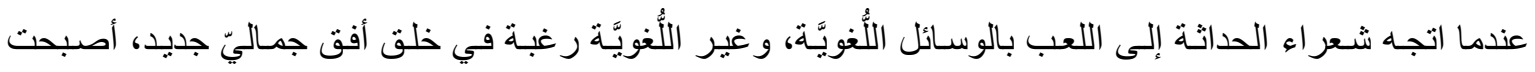

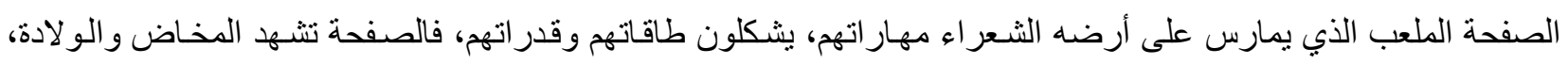

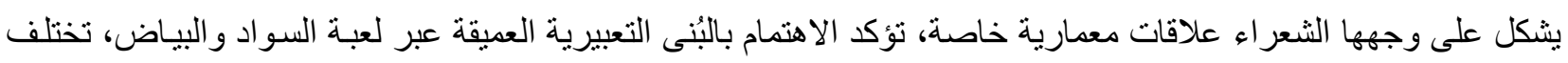

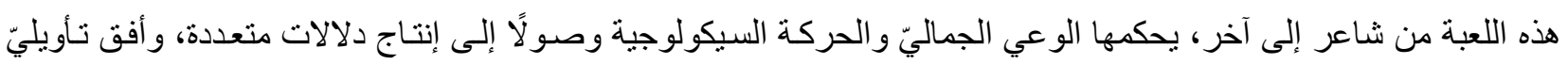

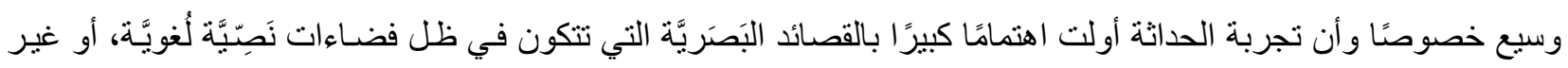

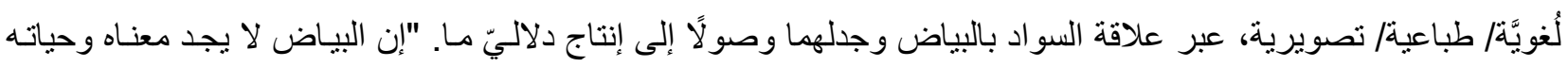

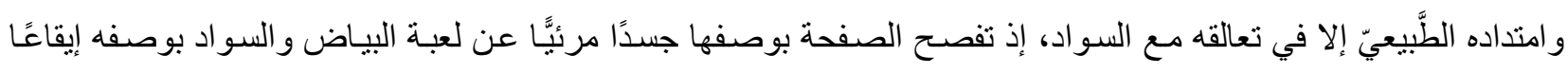

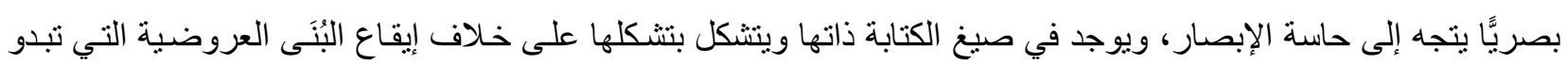

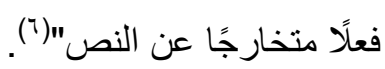

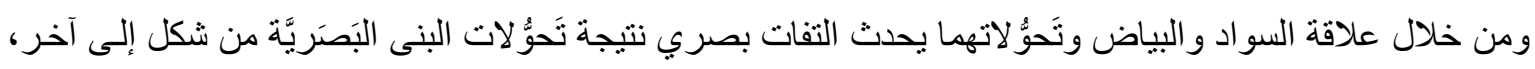

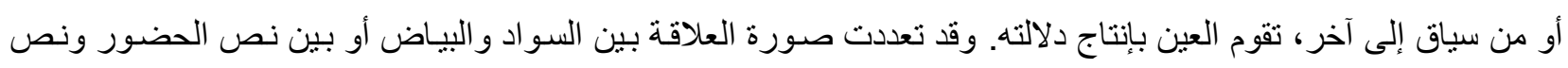

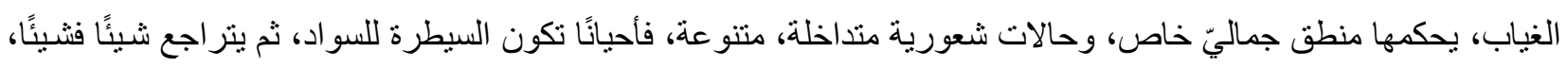

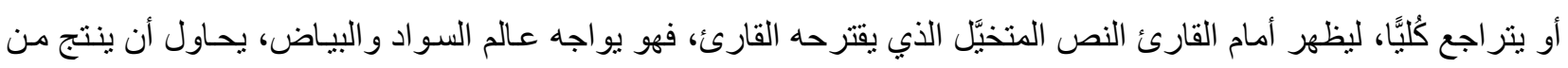

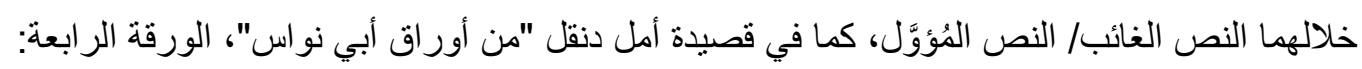




\section{أيها الشعر . . يا أيها الفرح المُختلَس \\ كل ما كنت أكتب في هذه الصفحة الورقية

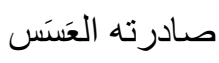

( $v$ )

عندما بطالع القارئ الصفحة وطريقة تشكيلها يجد نفسـه أمسام بنيتين للبياض، يتعالق معهما السواد، الأولى: البياض

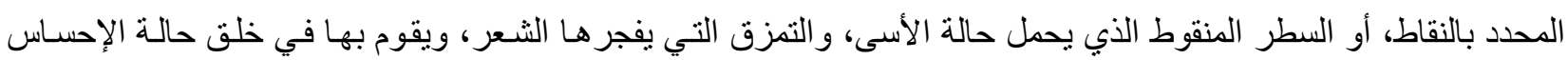
بالوجود، فقد التفت عن الدذكور: الثعر/ الفرح المختلَس، واستخدم النداء الذي يكثف عن الود و التمـاهي مع الثـعر الوسيلة الوحيدة لمواجهة العالم.

أما البنيَّة الثانية: فتتمثل في البياض غير المحدود، أو بياض الانتثار الذي يهيمن على الصفحة كلها، حيث يتخلص

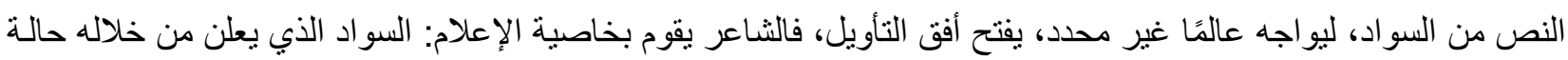

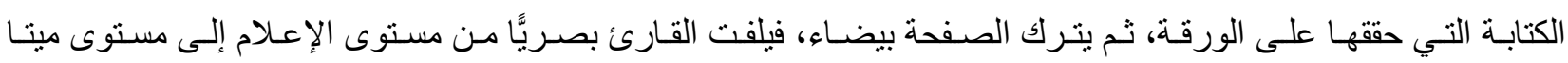

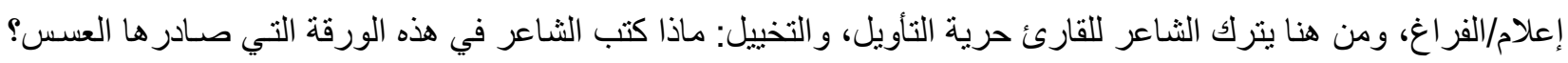

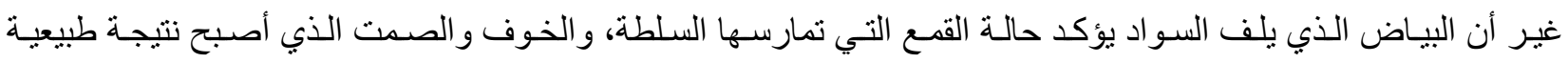

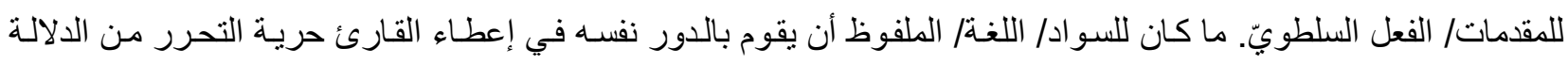

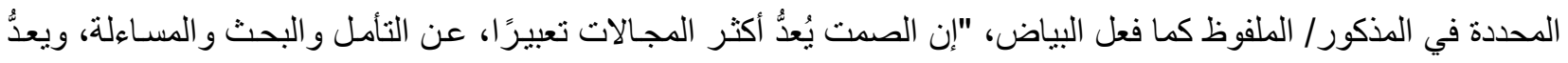

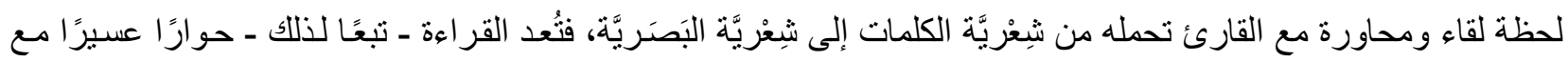
نص يلتهمه البياض و انخر اطا في مغامرة لا تعرف النهايـة من أجل إنتاج القصيدة التي لم تُكتب"|(^). و هنالك قصائد كاملة -

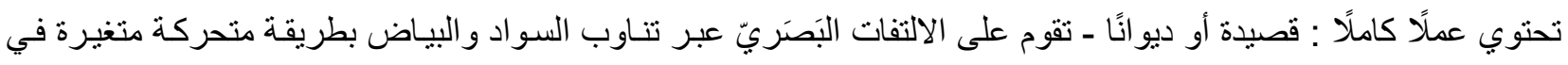
حضور كل منهما؛ مما يخلق بِنْيَة معقدة عميقة، متعددة، درامية، مفتوحة على احتمالات كثيرة، فقد تحولت القصيدة الجديدة إلى لى

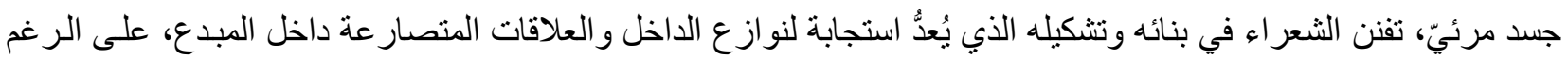
من حدة و عيه ونوقُّه.

الجانب النَّفْيّ يشد الوعي في اتجاهه، أو يستسلم هذا الوعي لحركة الانشغال، أو الاستغراق في التفكير الصـامت، أو

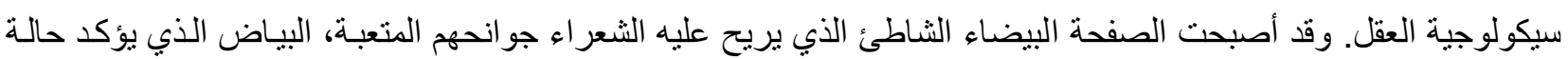

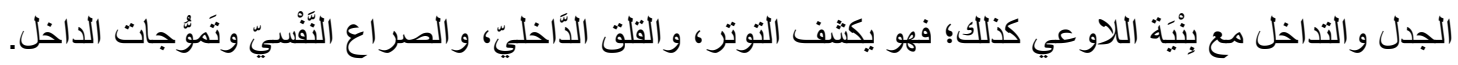
ومن القصائد التي اعتمدت في بنيتها على الالتفات البَصَربيّ عبر السو اد و البياض، قصبدة"شريف رزق"؛ حيث استغل

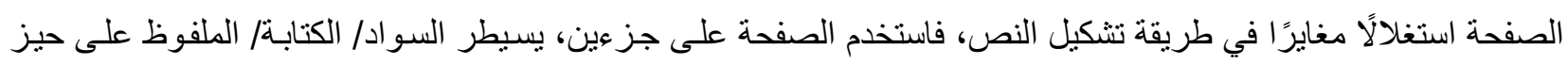
منها إما في اليسار ، وإما في اليمين، ثم يأتي النص المُو اذِي/ الغائب/ البياض على على الناحية الأخرى يمينًا أو يسارًا، شريف رزق في قصيدته "حَيَو ات مفقودة"؛ يستخدم ثنائيسة السواد و البيـاض عبر النص و النص المُو ازِي أو نص

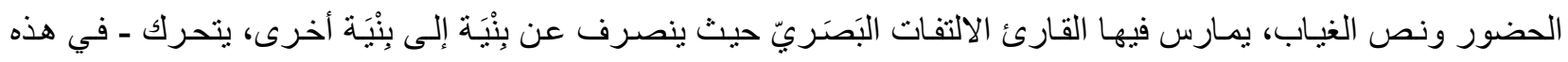

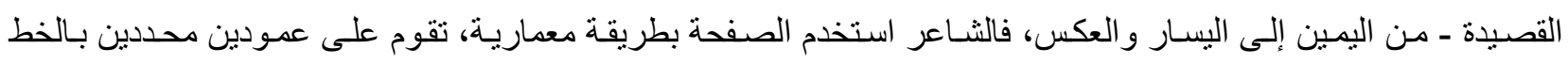




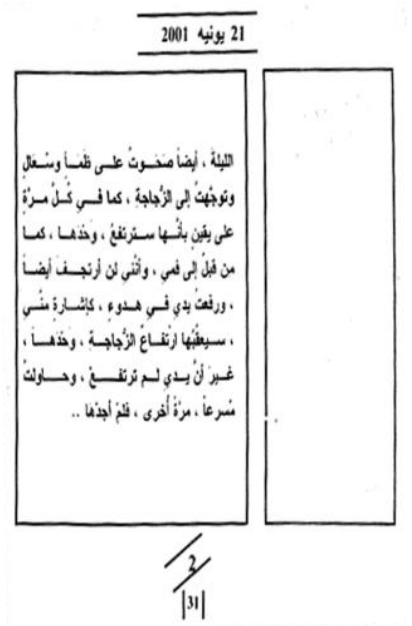

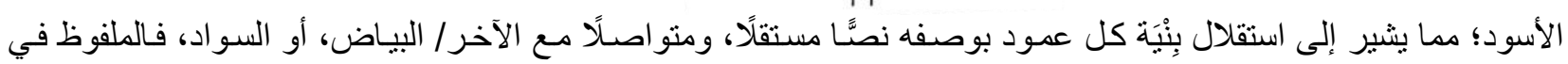

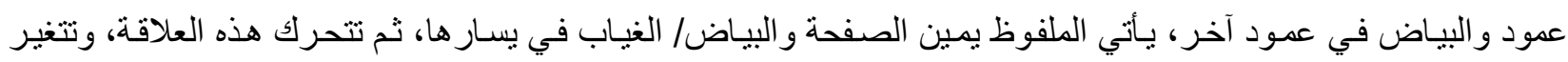

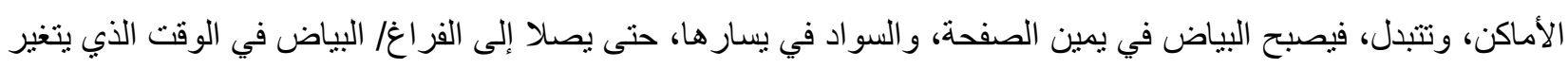
فيه اتجاه الملفوظ، فئكتب من أعلى إلى أسفل.

القصيدة نطرح حيوات مفقودة، كما يشير العنوان، كما تمارس فيها الذات حضورًا حَرَكيَّا مكبلًا عبر النوم و اليقظة،

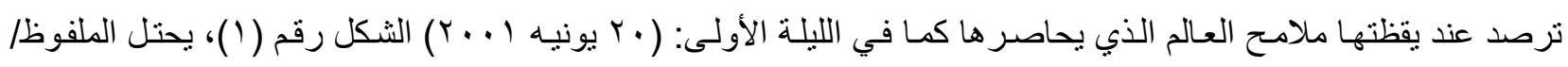

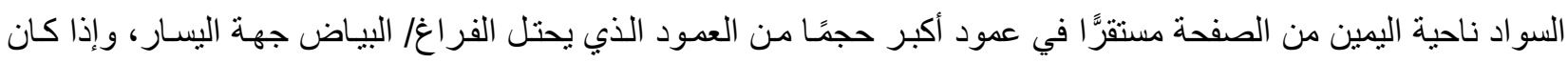

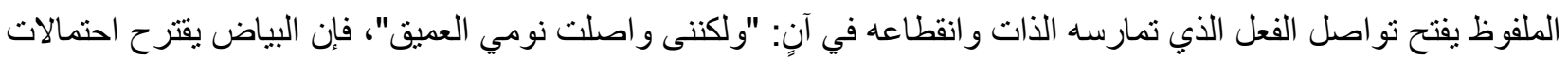
عدة أمام القارى؛ لأنه "ينهض بوظائف مختلفة، إذ يعيد تنظيم الكلام على نحو جديد، وهو إلى جانب ذلك ولك شكل من أشكال

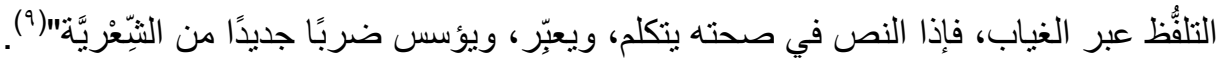

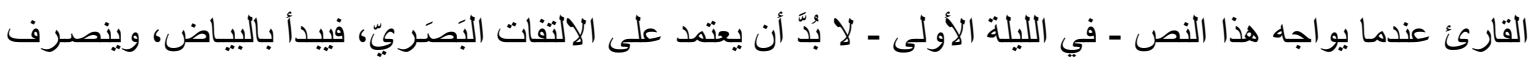

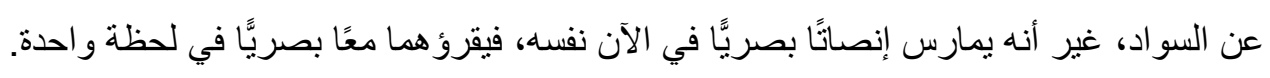
لقد قضت الذات ليلتها الأولى في نواصل الغياب عبر النوم، و عندما تستنقظ لتو اجه الوجود العينيّ/ الملفوظ فإنها

$$
\text { نو اجه انهيار ها ومعاناتها: -"صحوت على ظماً وسعال" }
$$

كما أن الذات التي خُدعت في الملفوظ رقم ( ) و اختبأت خلف نومها لتو اجه الفَقْد و الضياع تواجه من جديد - في

$$
\text { الملفوظ رقم (r) - عبر اليقظة الموت/ الظماً - وتكتثف - في ظل لهفتها - سراب الوجود: حياة مفقودة: }
$$

وفي الثكل رقم (r) يمارس القارئ التفاتًا بصريًّا حين ينصرف عن السو اد/ الملفوظ في الثكل رقم (Y) الموجود في الجانب الأيسر ، ليعود إلى مو اجهة البياض الذي يحتل العمود الأيمن. في الوقت الذي يمـارس فيه السواد رقم (Y) حضوره

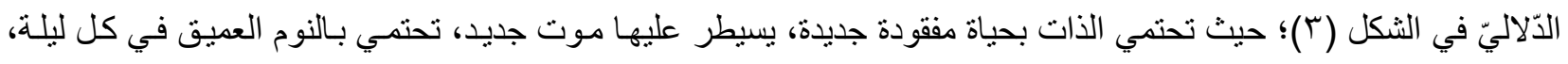

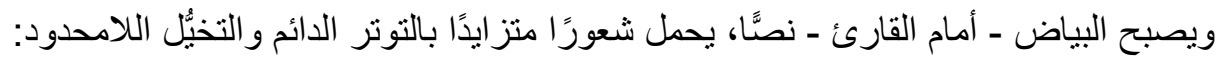



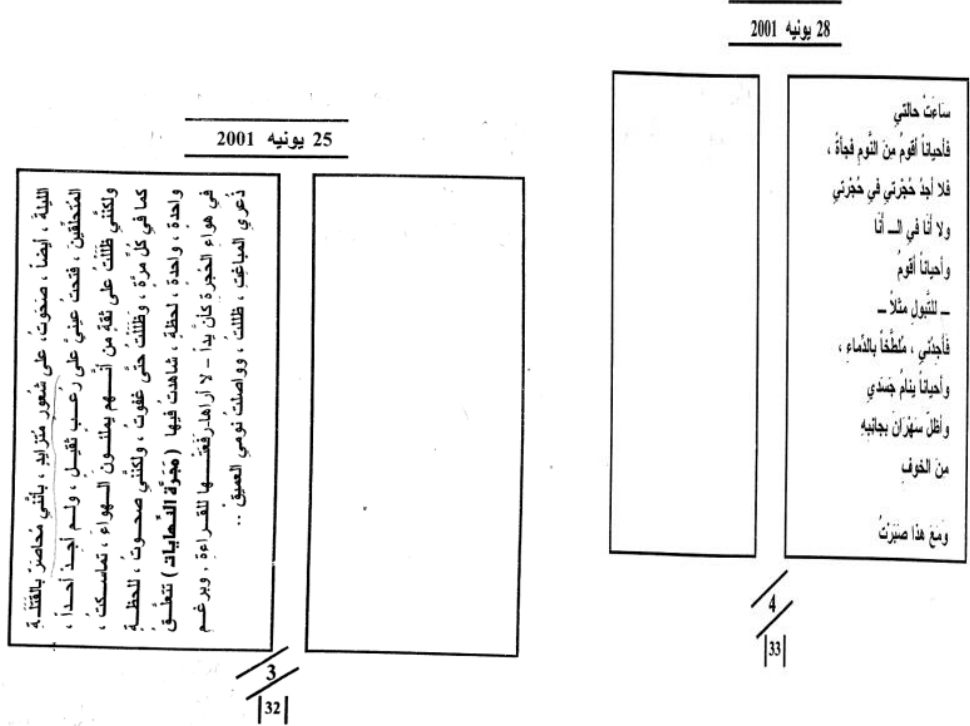

كما أن القارئ عندما يو اجه هذا النص، ويلتقت عن البياض إلى السو اد فإنه يو اجه التفاتًا جديدًا؛ حيث ينصرف - بعد

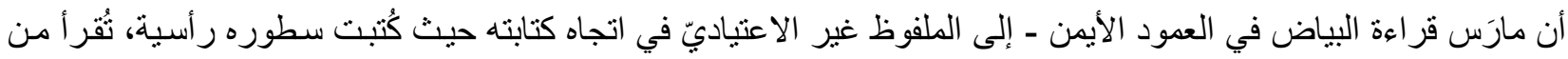

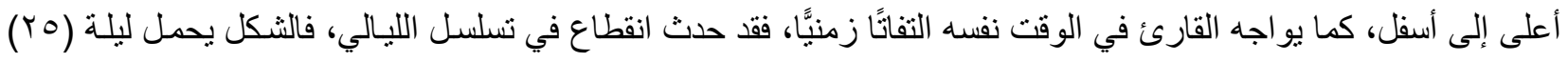

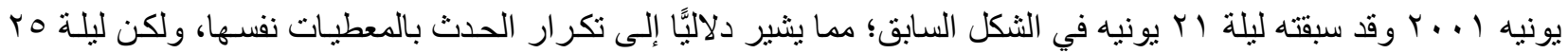

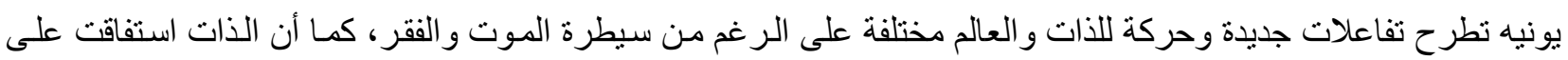
شعور متز ايد بالحصار ، و القهر، و الرعب، حاولت الهروب من المو اجهة بغفوة قليلة لتتوارى عن لحظة تقيلة، أصبحت بها الأشياء على غير عادتها.

وفي الثكل رقم (ع ) يتو الى الالتفات البَصَريّ بين السو اد و البياض من جهة؛ حيث يحتل الملفوظ جهة اليمين - مفارقًا

الصفحة السابقة - وبين السواد و السو اد من جهة أخرى، حيث تفارق عين القارئ الملفوظ المقلوب في العمود السـابق شكل (r) إلى الملفوظ الاعنياديّ في الثكل (ء):

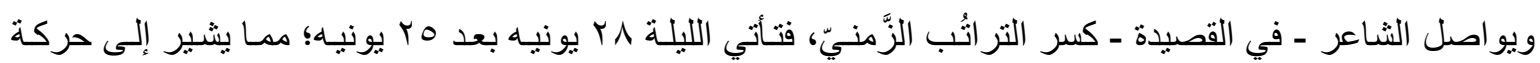

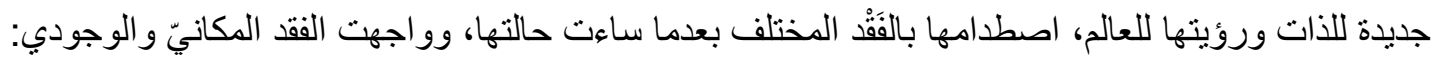

$$
\text { ولا أفلا أجد حجرتي في حجرني }
$$

وتعترف الذات من خلال الملفوظ/ السو اد باحتمالها:

$$
\text { "ومع هذا صبرت"، }
$$

ليوجه القارئ مساحة الاحتمال/ التنأيل في مساحة البياض جهة اليسار الذي يُعدُ مُتمًا. ويظل النص على حال التوتر مشدودًا للفراغ تارة، وللسو اد تارة أخرى، مُحققًا التفاتًا بصريًَا حرَكَيًا، يعمل على حيوية

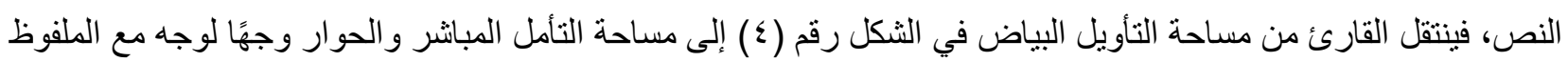

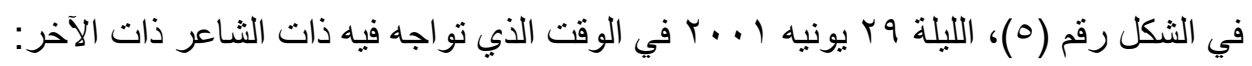




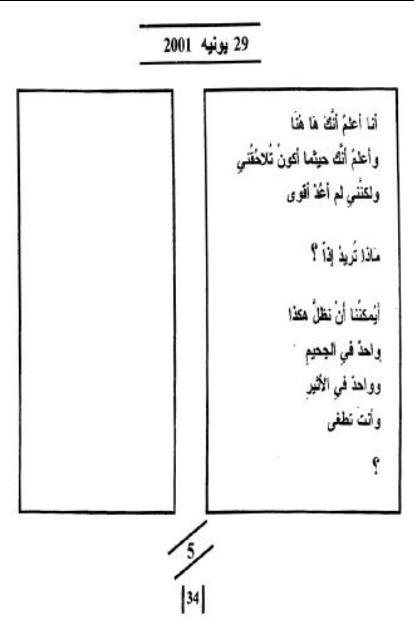

يُنهي الثشاعر السو اد/ الملفوظ في العمود السابق بالتساؤل الذي يؤكد وعيه بالتشكيل المكانيّ لنصـه؛ حيث يقرر عبر الالتفات

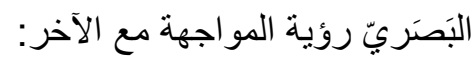

أيمكننا أن نظل هكذا واحد في الجحيم وواحد في الأثير وأنت تطغى. ?

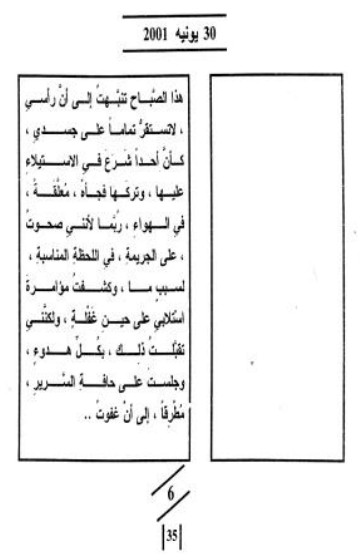

ويضع علامة الاستفهام في مساحة بيضاء تفتح مجال الانتشار للغياب و العدم في الصفحة التالية، حيث يلتفت النص

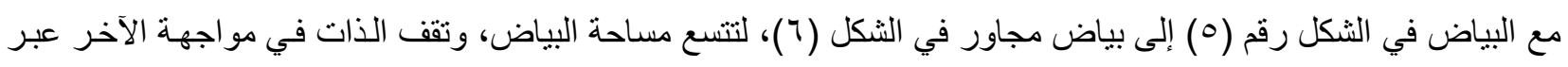

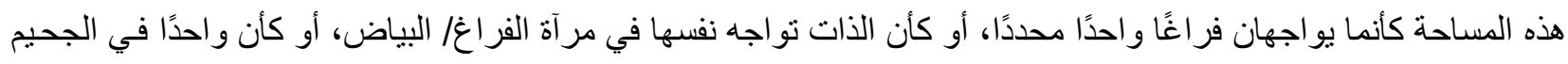

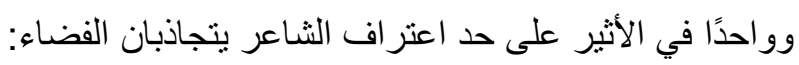
وفي الثكل (V) يجتاح البياض/ الغيابُ السو ادَ ويسيطر عليه، حيث تقلص التعبير الذي يؤكد حالذة العدم، و الغياب، و الموت واللاجدوى، إنها الإفاقة التامة التي تعانيها الذات بعد رحلة حيوات مفقودة عبر ليالٍ عدة، بعضها متتالٍ، وبعضهها غير 


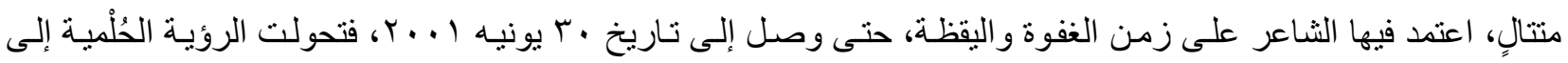

إدر الك نهاريّ تمارس فيه الذات صحوة مفاجئة:

$$
\text { "لا تهذا الصباح تنبهت إلى أن رأسي }
$$

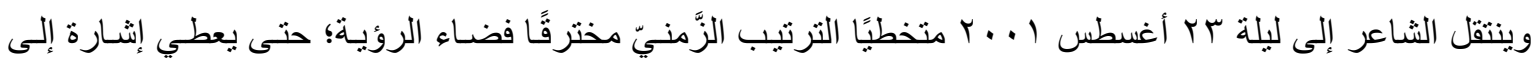
امتداد الحياة المفقودة عبر نو اصل إدر اكه للعالم:

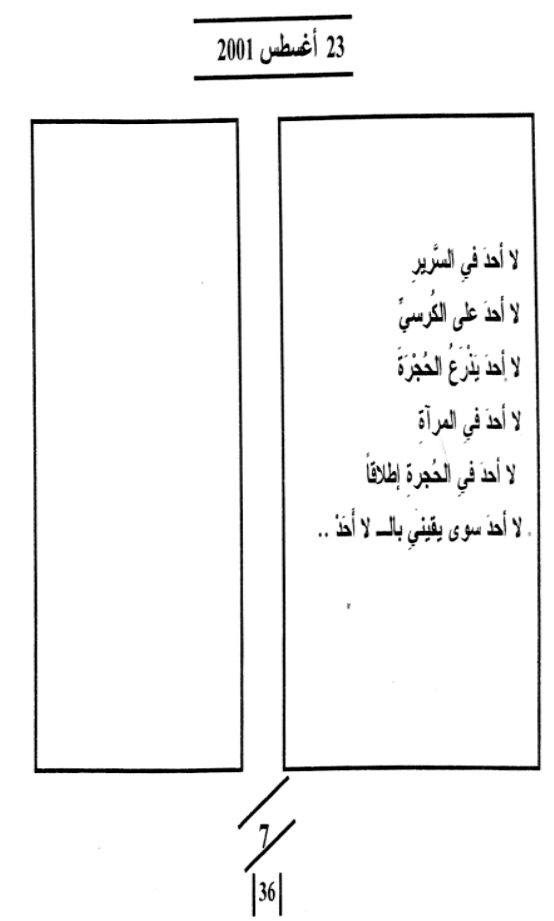

استطاع الثاعر أن يكتشف العدم المطلق و الغياب التام، ويكتشف خواء اليقظة والحلم أو الغفوة والإفاقة، وإنما وصلت

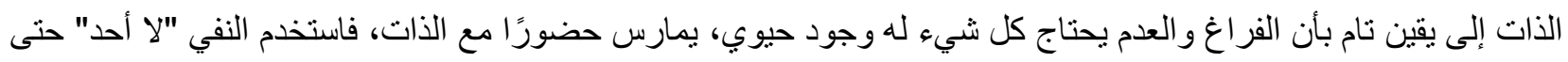

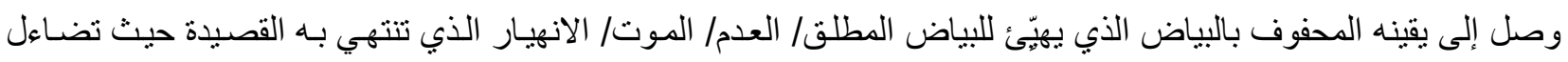

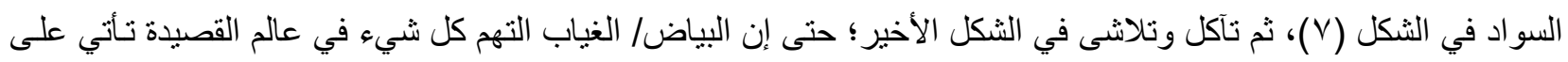
الترقيم في الثكل الأخير، و أصبحت الصفحة عبارة عن عمودين يسكنهما البياض التام، ليواجه القارئ نصنًا مفتوحًا، نصمَّا غائبًا حاضرًا، يقتر ح حضوره القارئ، نصنًا يعتمد على التأويل، و التخيُّل اللامحدود، نصنَّا يتعدد بتعدد قُرَّائه. في الوقت الذي يستشعر فيه القارئ بالعدم، و الفناء، و اكتساح الفراغ، وفي هذا يعتبر اكتساح البياضات للصفحة تأكيدًا

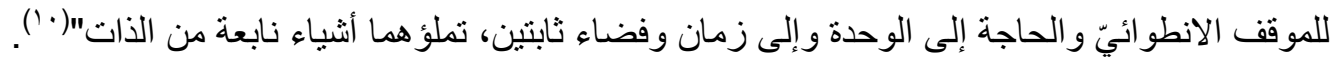




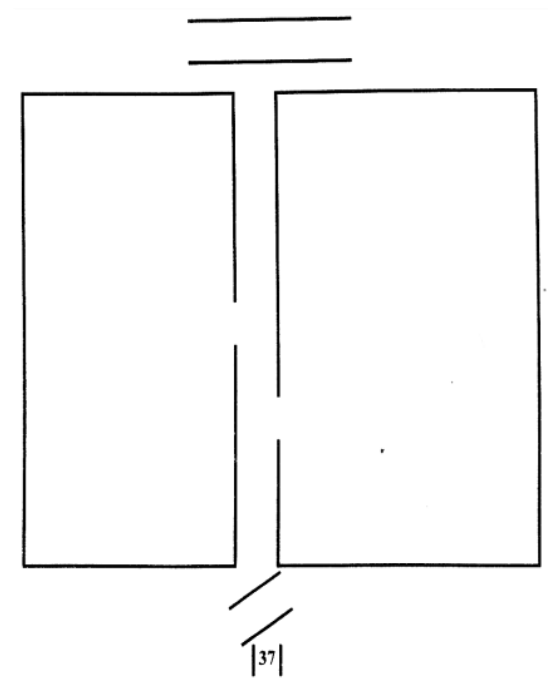

كما أن الثاعر - في الثكل السابق ـ لم يضع تاريخًا في أعلى الصحفة، كما فعل في اليوميات السابقة على الرغم من

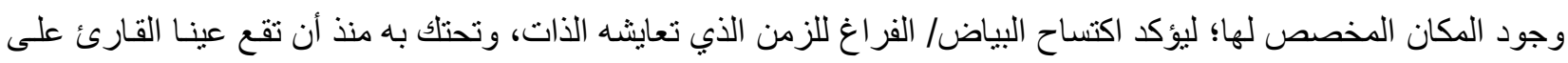
الصفحة، فيعيش عالم التأويل و الاقتر اح الديموميّ الحُرّكيّ: نستطيع القول أن لعبـة السو ادو البياض في قصيدة الحداثة لم تصبح عملًا مجَّانيَّا، أو فعلًا برييًا خاليًا من قَصْديَّة

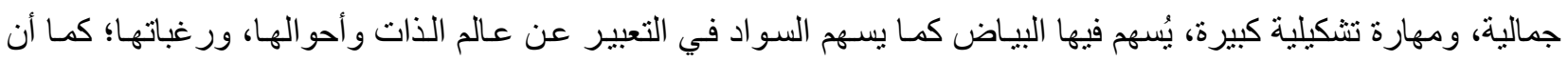

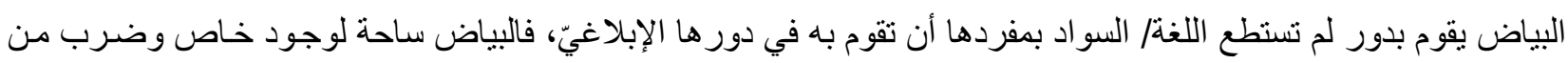

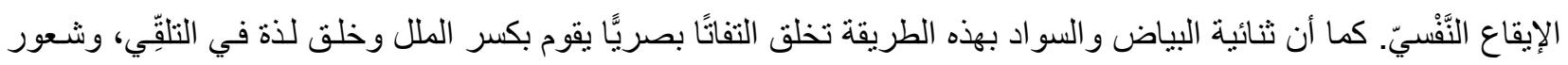

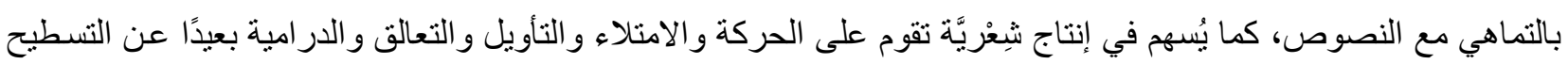
والغنائية الساذَجة، أو رومانسية الأضو اءو الخافتنة.

\section{الالتفات البَصَريّ عبر سُُنك الفط}

اهنَّ الثعر العربيّ على امتداد عصوره بالمثير ات الأسلوبية؛ خصوصًا النبر بوصفه منبهًا ومثيرًا سمعيَّا، تحظى بـهـ

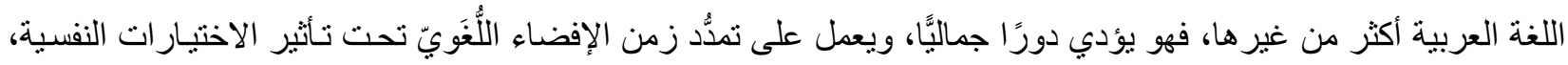

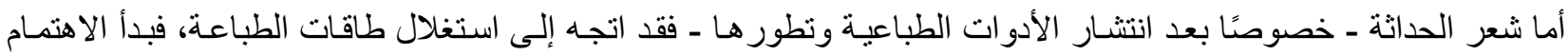

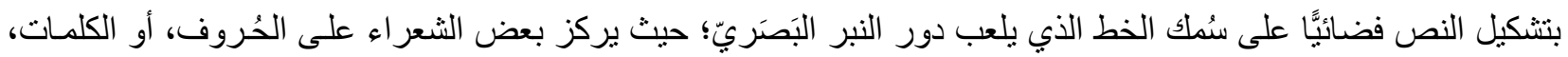

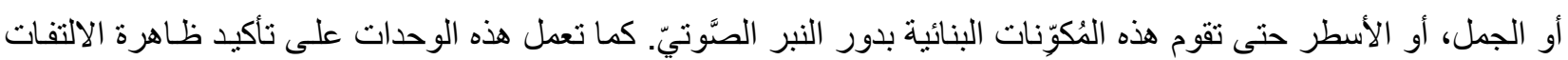

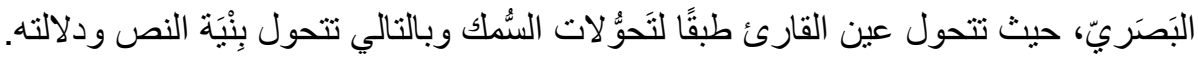

وقد تعددت وحدات النبر البَصَريّ في القصيدة الجديدة، وتعددت دلالاتها، فالثـعر اء يستخدمون النبر البَصَريّ مقطعًا

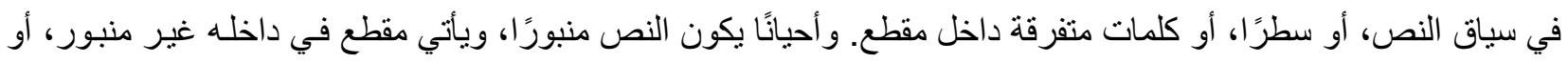

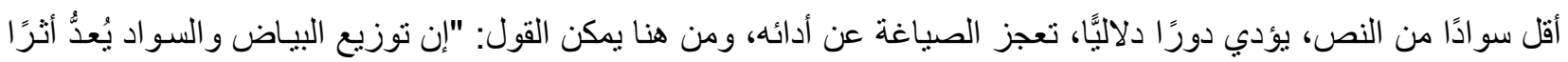

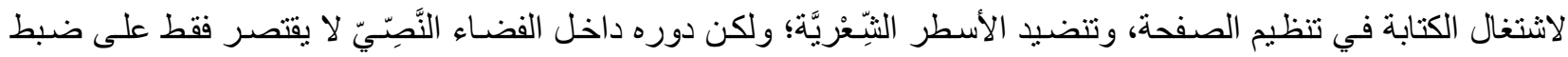
نظامه، بل يمكن أن يتجاوز ذلك إلى تقديم دلالات أيقونية، إما في ارتباطه بالمنتَج أو في علاقته بالسياق النَّصِيّي" ('). 
استخدم "رفعت سلام" النبر البَصَريّ/ سُمك الخط في إطار كلمـة أو كلمـات متفرقة داخل مقطع - في ديوانـه: "كأنها

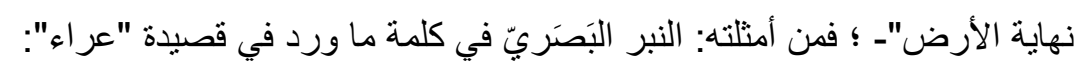

تأتي:

مدججة بالمر اثي و المواريث و الأمومة و البربري الأخبر.

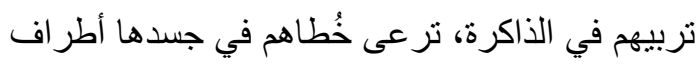

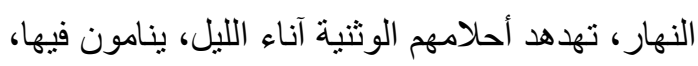

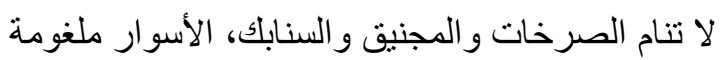

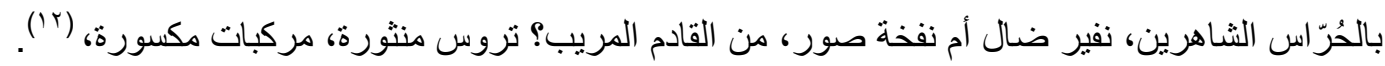

استخدم رفعت سلام كلمة "تأتي" في بداية القصيدة في سُمْك مختلف عن سمك الخط الذي كُبت بـه القصيدة، فجاءت

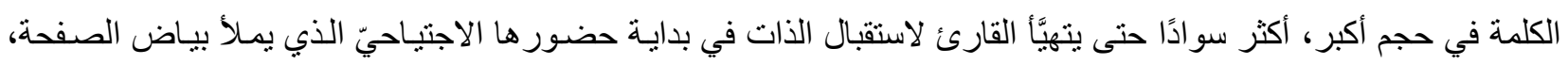

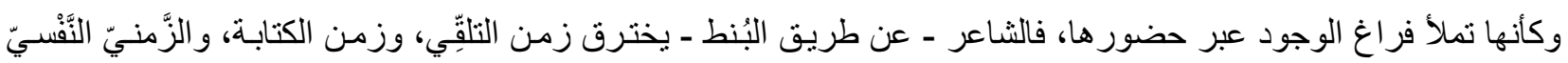

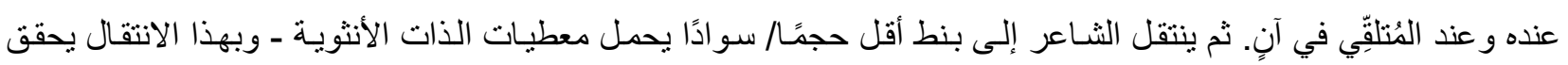

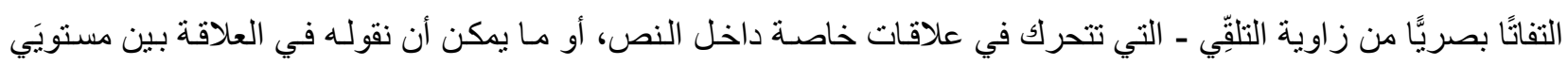

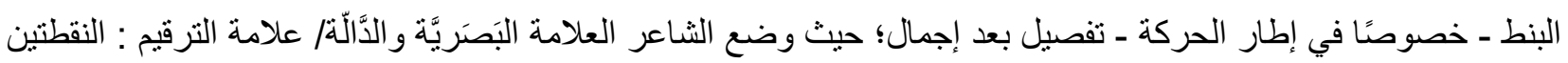

$$
\text { المتعامدتين بعد كلمة "تأني". }
$$

ويتحقق الالتفات البَصَريّ عبر نز اوج سُمك الخط، فيكون النَّبر البَصَريّ في جملة، ثم يلتقت النص عنها إلى حجم

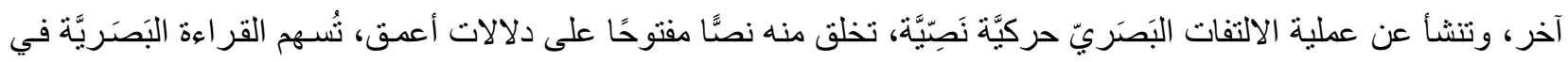

$$
\begin{aligned}
& \text { مر أة من نفايات يستدر إليها في انكسارة البصيرة، كيف؟ } \\
& \text { أيتها الطعنة العمياء، لا سكينة بعد اليوم و النوم قتيل } \\
& \text { جسدي مقبرة } \\
& \text { و أعضائي عويل } \\
& \text { من يوقف الرَّحى أخرج منها غبارًا غاربًا كل صمت وضغينة، } \\
& \text { سكين تمد جذورها، نورق البوم والغربان تنعق في خلاء }
\end{aligned}
$$

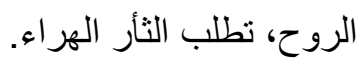

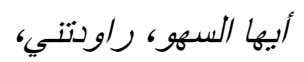

$$
\begin{aligned}
& \text { ورميتني إلى العراء } \\
& \text { دمي الحُرّام مسفوح } \\
& \text { على وجه العباء (r) ('). }
\end{aligned}
$$

يقرر الثـاعر و اقعًا مترديًا تحمله صورة المر أة، شعورًا بالألم وفقدان السَّكينة، إنه أفق نحو الموت، الذي يؤسس لـه الثـاعر بجسده، هذا الجسد الذي صـار مقبرة كبيرة قادرة على دفن الحياة بكل معطياتها، فيأتي الخط يُيرز هذا لئهو الحضور 
و الاحتواء: حضور الجسد والموت في آنٍ، فالثاعر لا يملك إلا جسده، يُعبأ فيه العدم والفَّدّ والغياب، في الوقت الذي يركز فيه

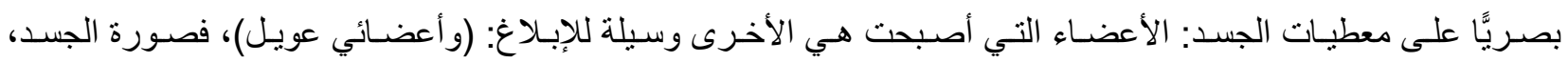
و المقبرة، والأعضاء، و العويل، تفارق الصوت البَصَريّ الذي ينبني عليه النص وسائر مفرداته.

استخدم أدونيس مستويين من الأداء الكتابيّ الخَظِّيّ، حيث تبدأ الدفقة بخط سميك بـارز، يمثل صوت الثـاعر الداعي

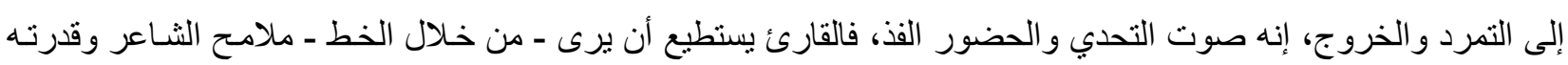

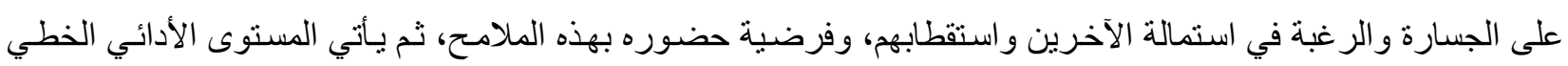

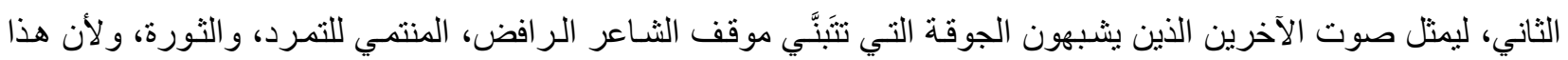
الصوت صوت تابع لصوت الثـاعر فقد جاء خافتًا، مختلفًا عن صوت الثـاعر على الرغم من تداخلهما في الفعل و الرؤيـة، حيث تعانقا معًا، ليمارسا دورًا واحدًا، غير أن هذه الأصوات بقيت فئ واهنة ضعنيفة في حاجة إلى صوت الثناعر. لقد استطاع أدونيس عن طريق حجم الخط/ سُمكه أن يكثف هذه الثنائيسة المتضـادة في الحضور ، وأن يخلق التفاتًا بصريًّا قادرًا على خلق دلالات منعددة.

أما الخط الأقل سو ادًا أو سُمكًا فإنه يكثف مفردات العالم، أو مـا يطلق عليه الثـاعر الملكوت في صورة متشظية،

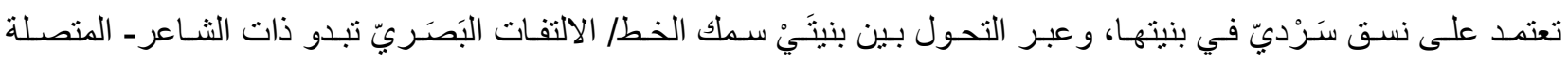

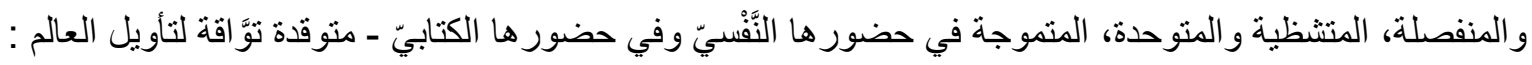
"إننا عندما نكتب نتموضع داخل فضائنا الخطي، ونكون في نفس الوقت ممثلًا ومتفرجًا، إننا نكتب، وننظر إلى أنفسنا ونحن نكتب نستمع إلى كلامنا الصامت الذي يصاحب البناء؛ لهذا وجب أن يكون مـا نكتبه ــ كأبعاد وأثكال وتنظيم - مناسبًا

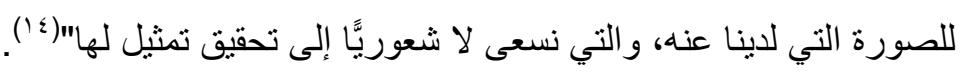
إذن لم تصبح أدوات التشكيل النَّهِّيّ بسيطة مثل ذي قبل حيث الاعتمـاد على الكتابـة اليدويـة، ولكن الطباعـة الحديثة

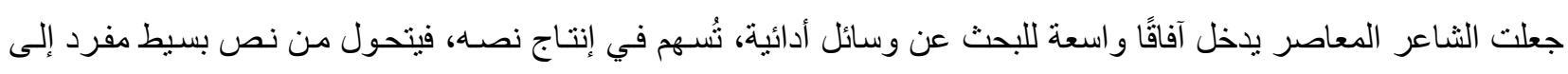

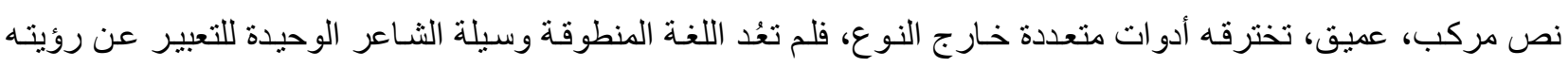
و عالمه؛ بل فتح الثاعر المجال أمام القارئ لاستغلال حواسيّه في إدرات الك جماليَّاته الخاصنة.

\section{الالتفات البتصَريّ عبر النص والصورة}

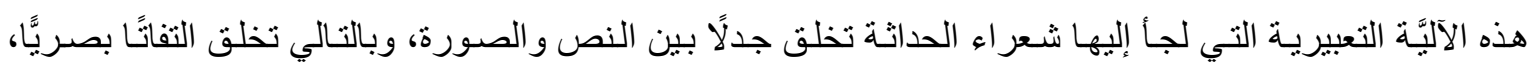

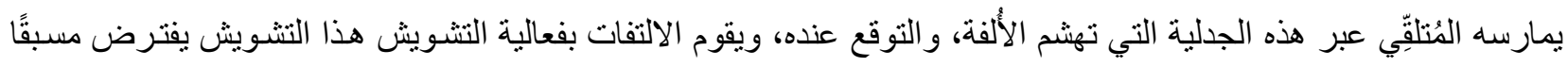
حضور مؤلف وقصده المرتبط باللعب؛ الأمر الذي يثجع على القيام بمقارنـة. و لا شك طبعًا في أنتـا لا نسنطيع إقامـة تحليل

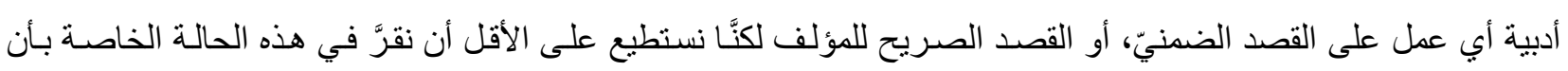

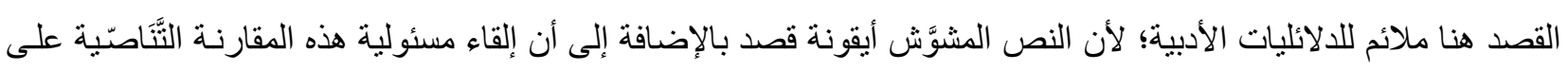

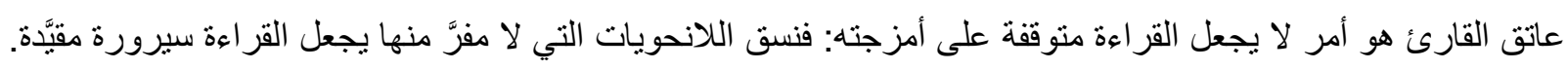

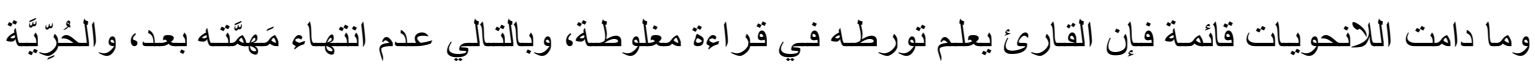

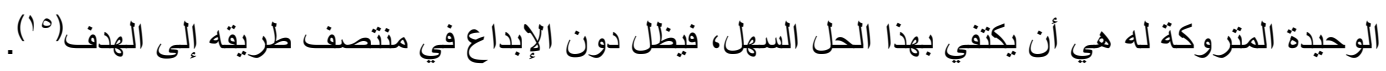

\section{-YIE_}


ومن الأعمال التي حققت التفاتًا بصريًًا عبر المزج بين النص و الصورة ديوان "شجن" لـ (علاء عبدالهادي) الذي يُعدُ

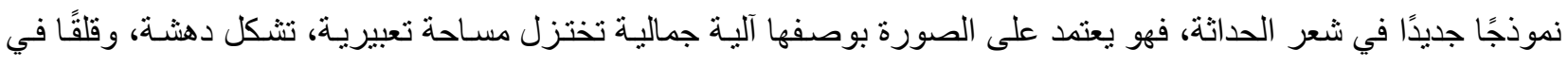

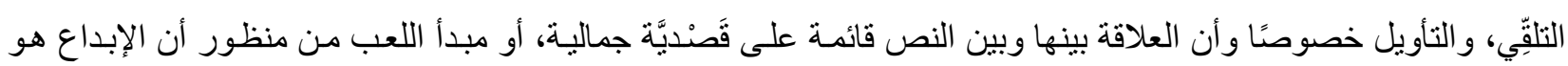

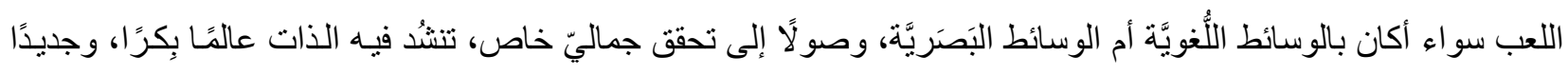

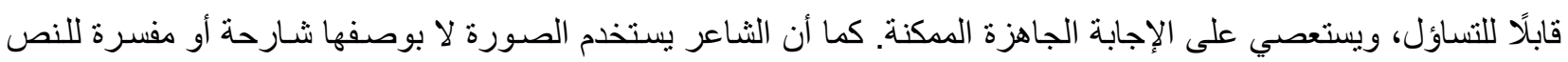
لكنها تقوم على الجدل و التماهي. يصرح الثشاعر بإجر اءاته الجمالية في هذا الديوان بقوله: "جاء هذا الديوان منقطعًا عما سبقه من أعمالي الثِِّّرَيَّة على

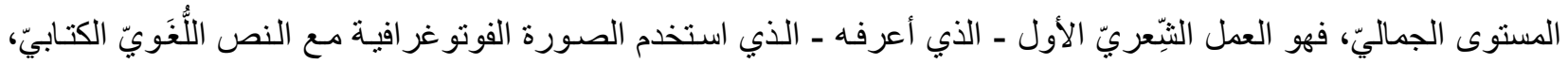

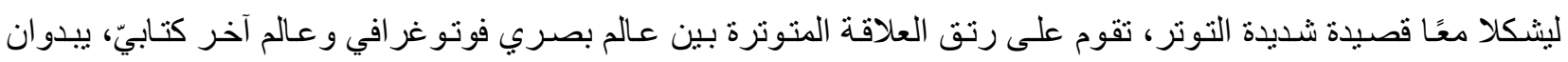

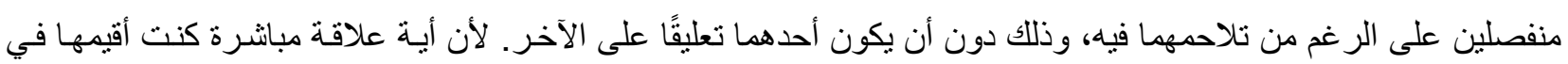

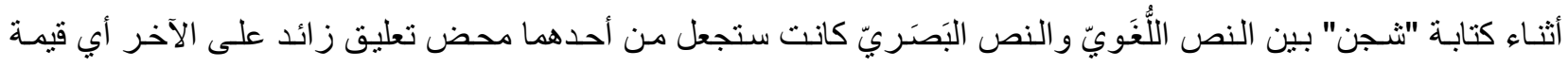

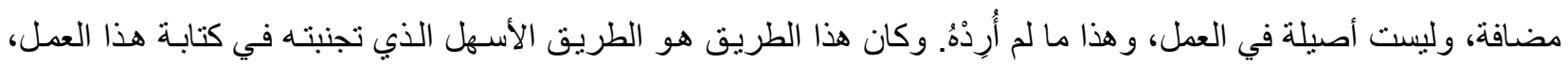

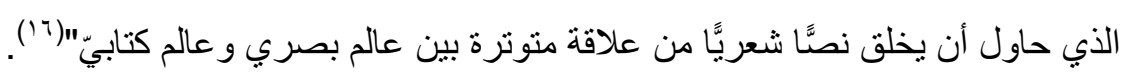

يقوم ديوان "شجن" كله على الثنائية بين النص و الصورة دون الفصل بينهما - بل إن العلاقة في كل صفحة تقوم على تلى

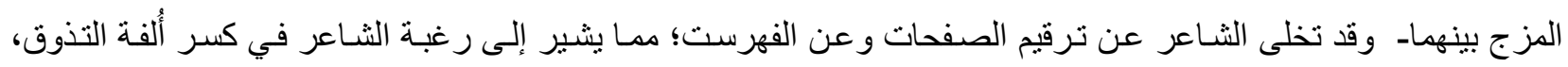
وتحطيم النمطية في التلقِيّ، وكسر التوقع؛ حتى تنشأ علاقة اعتباطية عفويـة، ومن هنا ينفتح النص على القارئ قبل أن ينفتح

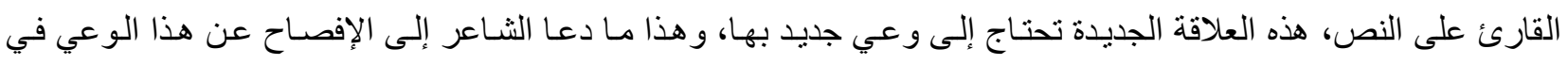

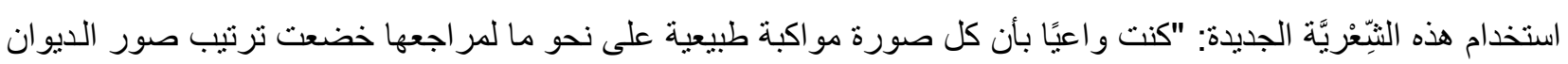

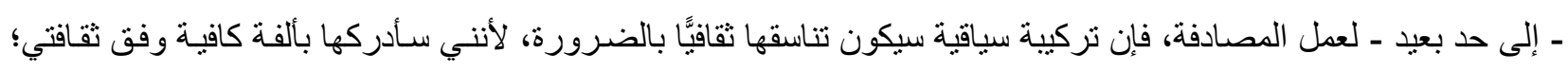

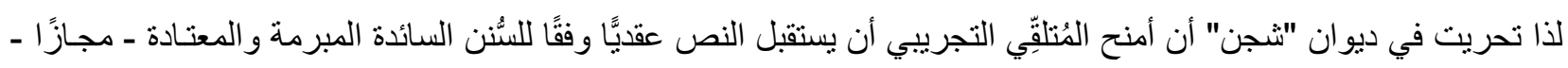

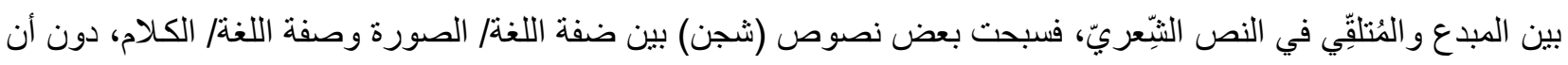

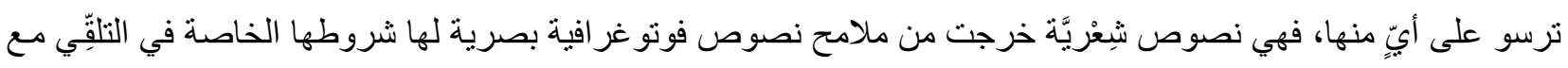

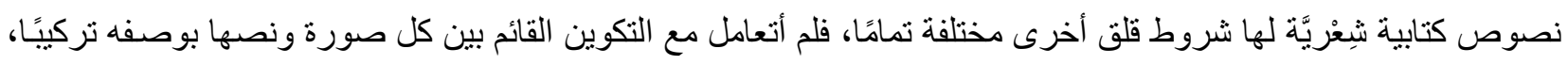

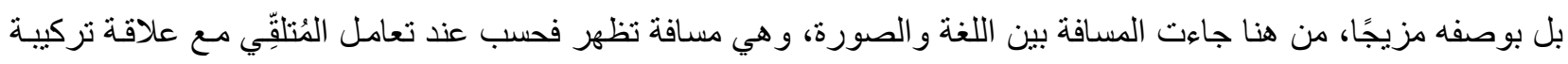

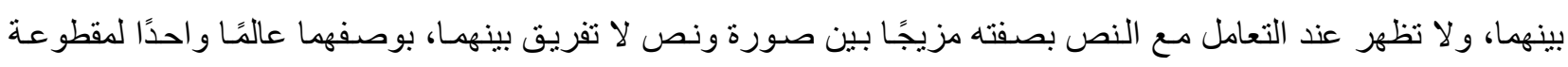

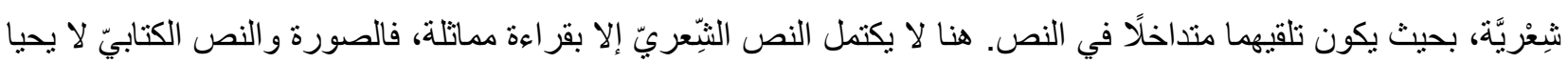

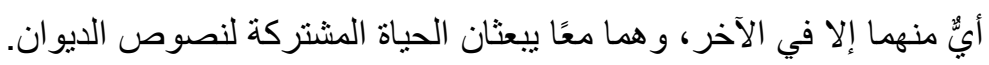
استطاع علاء عبدالهادي- من خلال مزجه بين الصورة و النص - أن يخلق إنصانًا بصريًا - ومعناه أن ينصت القارئ

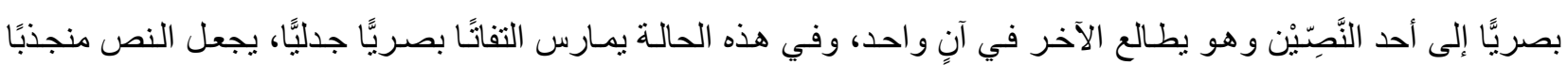
للصورة والصورة منجذبة للنص، فلا وجود لأحدهما بعيدًا عن الآخر، إنها علاقة حياة تقوم العين برسم حدودها وأُ أُقها المفتوح 


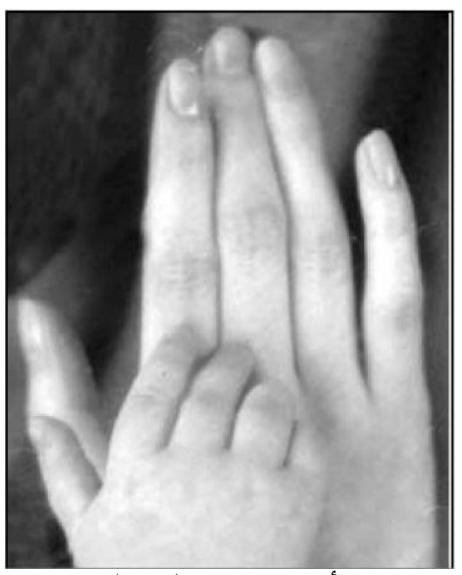

عندما نطالع صفحة من صفحات الديوان نجد أنها تعتمد على الصورة في أعلى الصفحة - هذه الصورة عبارة عن

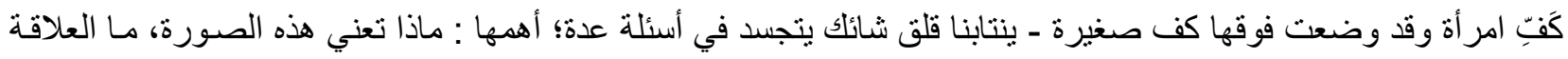
بين كف المرأة وهذه الكف التي وضعت عليها؟ ما الدلالة التي تتحقق عبر علاقتهما؟ هل الصورة تفرض نصنًا يتعالق معها ؟ في ظل هذا القلق و هذه الحيرة التي تعرضها مجموعـة الأسئلة السـابقة وغير هـا، فإن القارئ يستمر في القيام بعملية الالتفات البَصَريّ عبر شطرَي العلاقة: النص و الصورة ـ كما يقوم - في قراءته ـ باستخدام آلية الإنصات البَصَريّ:

$$
\begin{aligned}
& \text { عندما مات زوجها } \\
& \text { غطت شفتيها بالصر اخ، } \\
& \text { فقد كان العشيق حاضر ا } \\
& \text { وهي } \\
& \text { تستدعى أمطارًا غزيرة } \\
& \text { كى تخفي فرحها. }
\end{aligned}
$$

القارئ عندما يو اجه هذه الصفحة يتوقف أولًا مع الصورة في أعلى الصفحة محاولًا قراعتها أولًا، ثم يجد نفسـه أمسام

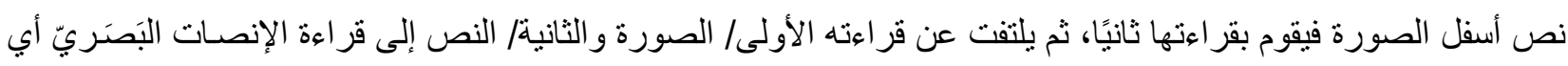

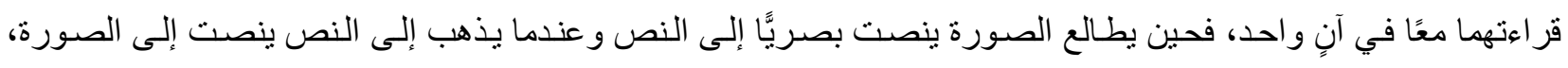

$$
\text { فيسمع/ يرى صوتين في آنٍ واحد. }
$$

النص يطرح فكرة الخيانة الزوجية، هذه الدلالة تتجلى في الإشارة اللُّويَّة "العشيق" الذي يختزل فعل/ زمن الخيانة

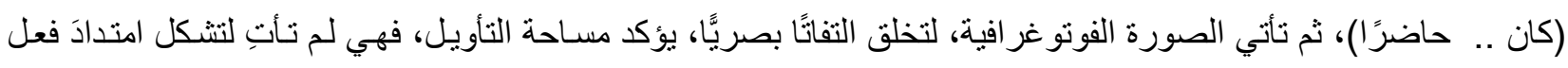

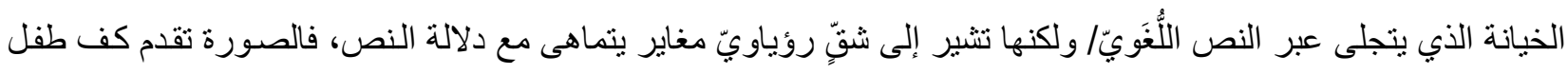

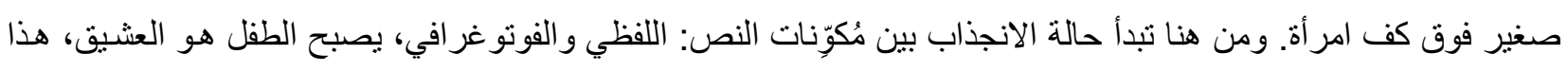
الطفل الذي تهب المر أة حياتها له بعدما فارقها زوجها. لقد قام الالتفات البَصَريّ - عبر حركة النص و الصورة - بتحويل المعنى من الخيانة الذي يطرحهـ النص عبر وسـائله

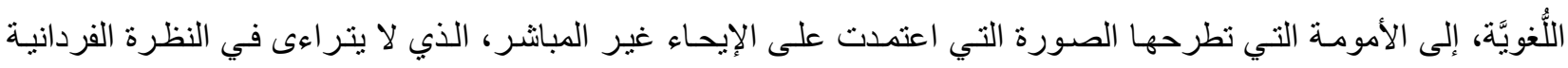

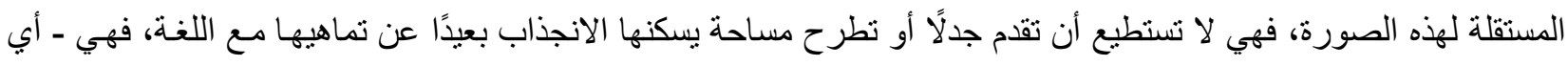




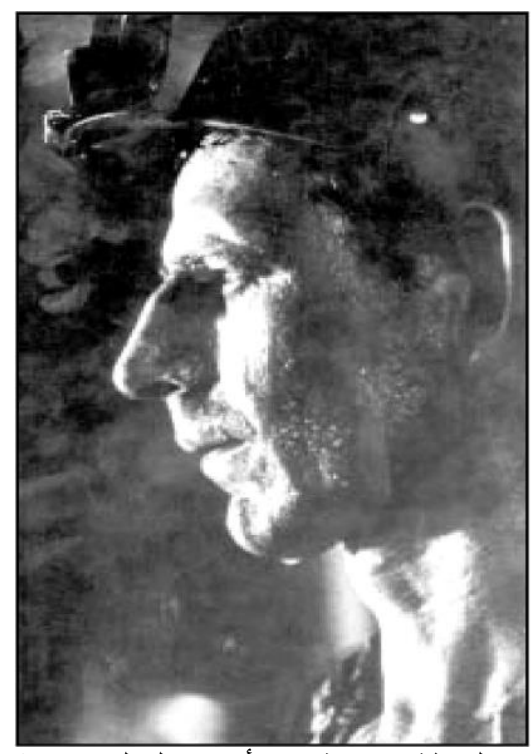

الصورة ـ أصبحت تجسيدًا لانفعال الثاعر في لحظة خاصة، يقر أ فِيها العالم عبر ذاته الثِِّّرِيَّة.

يمارس الثشاعر - في إنتاج شِيُرْيَّة ديوانه ــ لعبة التبادل البَصَريّ بين النص والصورة على امتداد الديوان :

$$
\text { بعد أن وضع }
$$

العطر

$$
\text { ترك نبضه في المكان }
$$

الصورة تكثف ملامح عامل فقير، يطفر وجهه بالعرق، وقد بدا مكدود الوجهه من عنـاء العمل، يتفرس بعينيه الأفق الممتد، فهو الذي يصنع الغد والأمل بوصفه منتجًا. أما النص فيطرح ملامح رجل يضع العطر، ويترك المكان ويختفي. فالقارئ عندما يمـارس وعي تلقِّهـ في إنتاج العلاقة فإنـه يؤكد أن الناتج الذي تطرحه اللوحة هو صنع الحياة عبر العمل، والجهد الذي يتجلى عبر معطيات الصورة: قطر ات العرق على الوجه، ثم يحدث الالتفات البَصَريّ إلى النص، فيحدث تحول في المعنى: فالعطر متحول عن قطرات العرق، والنبض الذي تُرك في المكان هو ما أنتجته يداه؛ إذن فالنص ينخلق بين

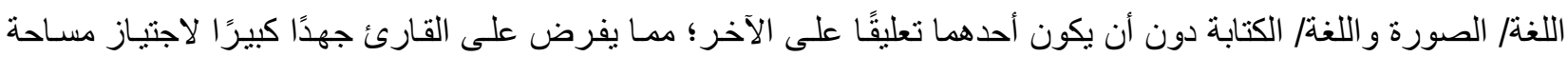

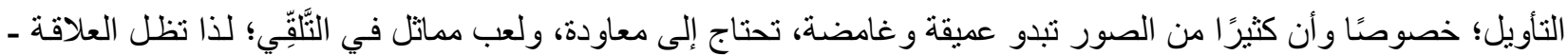

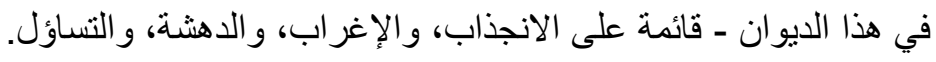

\section{الالتفات عبر الشكل الهُرّ والشكل التقليديّي}

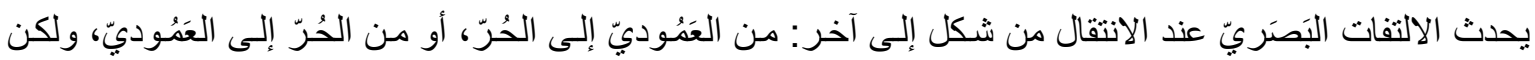

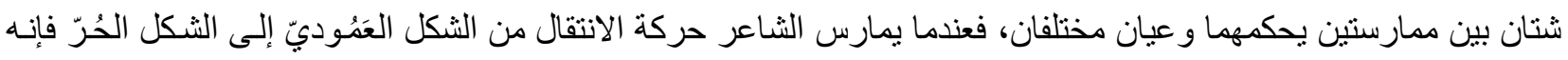

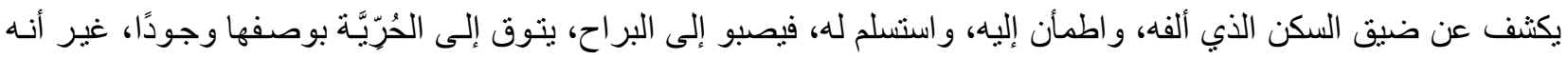

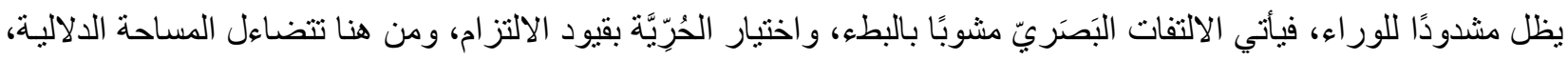


وتتقلص المتعة الجمالية؛ لأن الثناعر يكون - في إجر ائه البنائيّ/ التشكيليّ - مخلصًا للنمط الأساسى، القارِّ الثابت، الذي يألفه

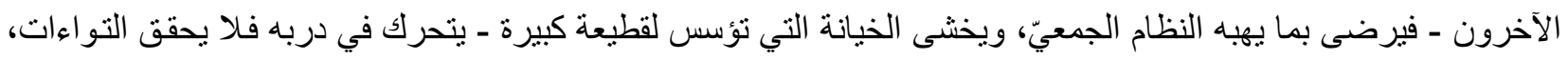

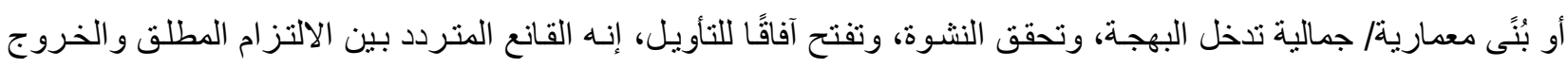

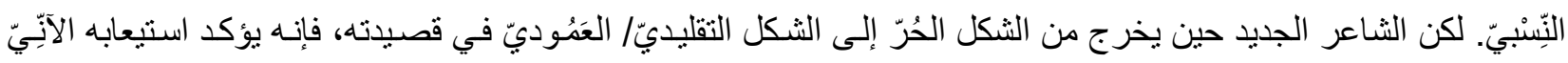

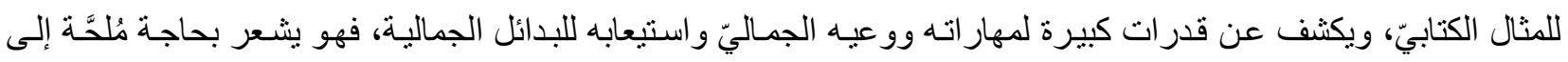

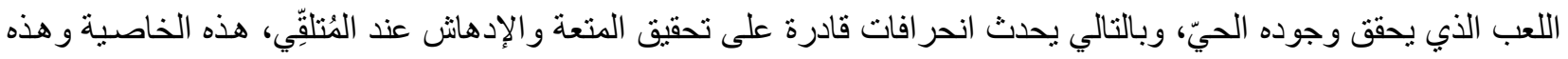

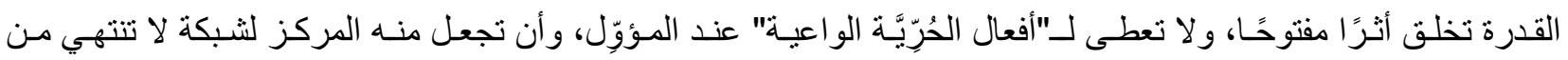
العلاقات"(') (ل)

و الثاعر الذي تستقيم له الأشياء لحظة ممارستها بسنطيع أن يخلق منها عالئًا متفردًا له خصوصيته، يرتبط باللحظة

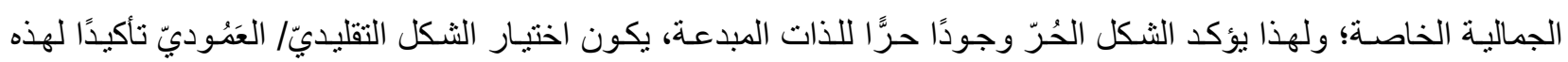
الحُرِّيَّة، وقدرنها على الحركة، فتبحث في المستقر الثابت عن حركة جديدة، ولحظة جمالية مختلفة، تكون إثشارة دالـة عبر

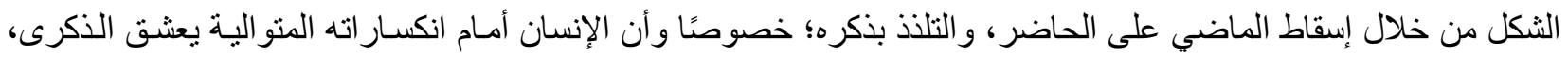

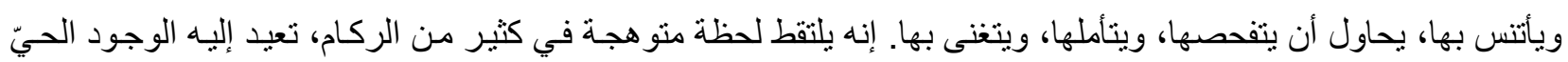

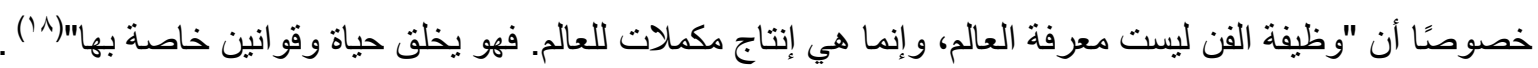
إنـه استـدعاء الثـموخ في مقابل الخنوع و الاستسـلام اللذين يهيمنـان على الو اقع المَعِيش، غير أنها علاقـة اتصـال

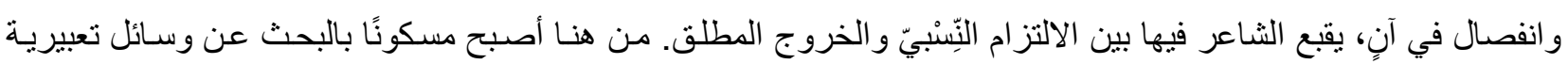

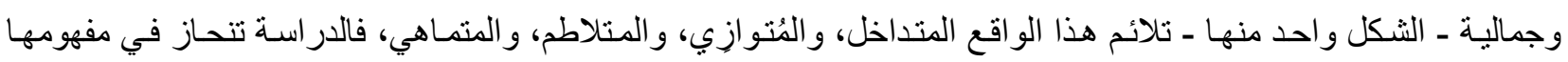

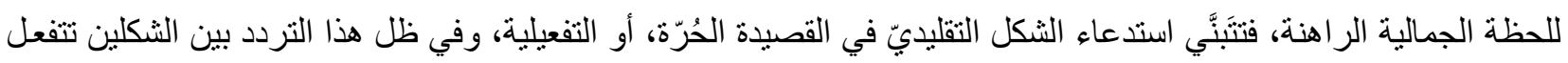

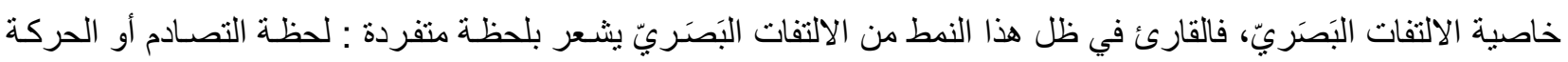

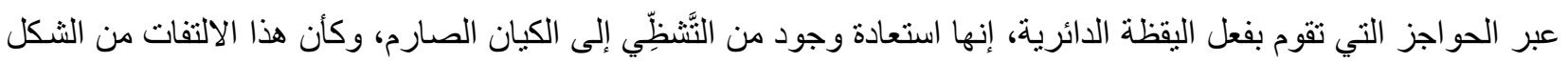
الحُرّ إلى الثكل العَمُوديّ يعبر عن لحظة/ حالة نفسية لا تعرف السير أو الحركة على وتيرة واحدة، وفي لحظة مفاجئة تنشُد الر احة، و التأمل، و التلذُّذ مع الحركة المنتظمة، كما يخلق الالتفات لحظات انتقال بين حالات نفسية متعددة ومتغيرة في آنٍ. ومن أمثلة هذا النوع من الالتفات مـا ورد في قصبدة "ضد البَنْهَجَ" للثـاعر حسن طِلِب؛ حيث استخدم ثلاثتة أُطُر شكلية حققت ظاهرة الالتفات البَصَريّ، حيث ينتقل من الثكل الحُرّ إلى التدوير إلى العَمُوديّ دو اليكا...

تبدأ القصيدة بالإطار الأول المتمثل في الشكل الحُرّ الذي عرفته القصيدة التفعيلية:

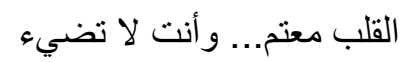

$$
\begin{aligned}
& \text { و الليل ليل... نو أم } \\
& \text { وكل شيء ذاهب } \\
& \text { وسالف الفساد و الكساد و الموت البطيء } \\
& \text { فإليك - ويك عني أيها البنفسج الرديء(19) . }
\end{aligned}
$$

ثم يلتقت حسن طلب إلى شكل آخر ، يعتمد على التدوير والامتداد الأفقيّ و المناجاة الصوفية التي يرى فيها تجسيدًا

\section{-YIA.}


لحالة تعاني ألمَ البَوْح و الكثثف على هيئة "المواقف والمخاطبات" بعيدًا عن الانفصال، أو التقطيع، أو الإيجاز ، أو الوقوف عبر عو امل لُغويَّة، أو غير ها مستسلمًا للتدفق و والعفوية: ألا يا أصحابي ويا أخدان ذاتي ويا خلصائي وشيعتي

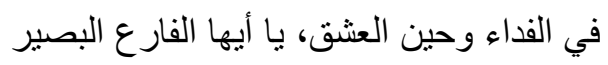
بالناسوت و المُطلّع على الأفئدة ويا أيها الكائن

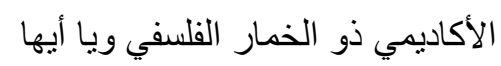

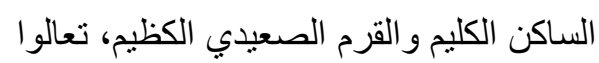

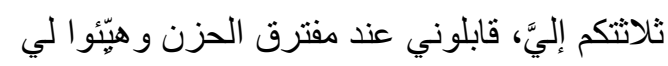

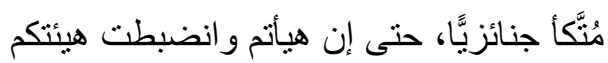

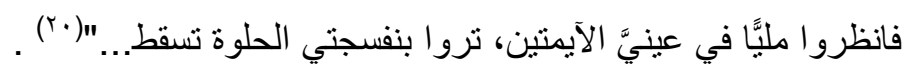
أمسا الإطسار الثالث الذي استخدمه حسن طلب في قصيدته ـ وقد مـارَس فيهه حركة الثكل/ الالتفـات البَصَربيّ عبر التناوب؛ فهو الثُكل العَوُوديّ، وقد مارسه في أكثر من موضع في قصيدته مُستخدمًا التتاوب بين الأشكال؛ رغبةًُ في إحداث

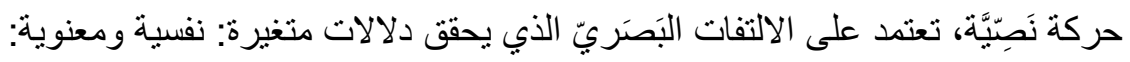

$$
\begin{aligned}
& \text { يناديك الأريج على الغصون } \\
& \text { بنفسة الندامة : عنك دوني } \\
& \text { متى تكون الخيانة فيلكِ طبعا } \\
& \text { فخوني ما حَلَا للكِ أن تخوني } \\
& \text { نثرت عليك من شعري فنونا } \\
& \text { ولو لا أنت ـ آزرت بالفنون } \\
& \text { يحيط الثعر أن تعزى إليه } \\
& \text { لأن الحب هان عليك:هونى (r) }
\end{aligned}
$$

يؤكد حسن طلب - من خلال ممارسته الثكلية ـ أن الثناعر الجديد يفجر كل إمكانات اللغة وطاقاتها الموسيقية، سواء أكان على المستوى العروضى أم المستوى الصرفي للكلمات، أم المستوى التركيبيّ للجمل من خلال علاقات المخارِِ الصوتية

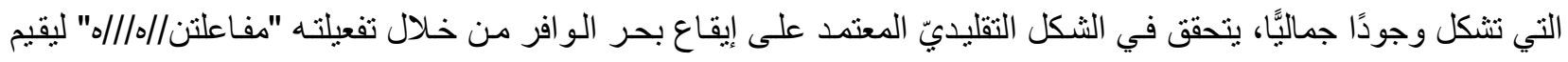

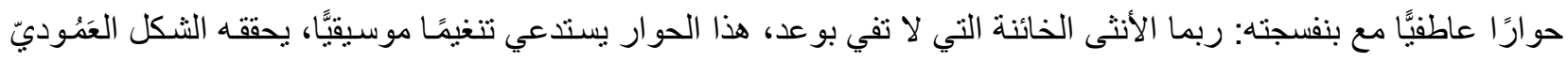
ذو السيمترية الموسيقية، كما أن فضاء القصيدة العمودية "فضاء شعري ممتد، تتماثل فيه الأشياء وتتشـابه، و هو أثنبه بفضـاء الصحر اء الرَّحب الممند، حيث تتنصب الخيام، وتثَّح الظلال؛ لأن حضور الثمس هنـا مر اقب عن كثب، و انتصـاب القصيدة

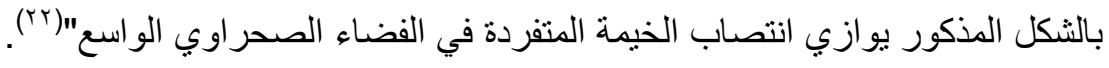
يلتقت القارئ بصريًَا عن الثكل التقليديّ - في الدقطع السابق - إلى الثكل الحُرّ: نفس السو اد ثُُّم....

\section{$-r \mid 9$.}




$$
\begin{aligned}
& \text { و الكساد و الموت البطيء } \\
& \text { فأين وجههك الوضيء } \\
& \text { يهل مثلما كان يُريني! } \\
& \text { هل خبا نورك؟ } \\
& \text { أم كلت عيونى؟ هل حورج }
\end{aligned}
$$

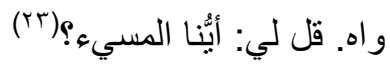

و عندما تعاود الثناعر حالة الصوفي المجاهد من أجل الوصول والنبي المؤرَّق/ الثـاعر بفجائيسة الوحي، فإنه بعاود

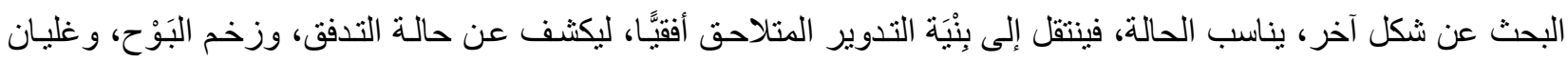
الإفاضة دفعة واحدة بلا نوقف أو إبطاء:

"زمِّلوني زملوني يا خاصَّني الأقربين واخشعو ا مليّا

$$
\begin{aligned}
& \text { مليَّا في حضرة البنفسج اللعين، ثم اتركوني كي } \\
& \text { أواجه الأنة بالأنة، حتى إن أنتت فاكتمل عليكم } \\
& \text { أنيني و انضبطت أنَّاتي، فدعوني كي أرمز للألم الماند }
\end{aligned}
$$

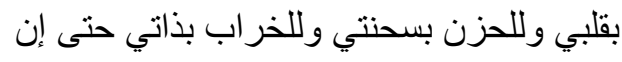

$$
\begin{aligned}
& \text { رمزت فاكتملت عليكم رموزي و انضبطت برموزاتي } \\
& \text { فذروني كي أسمي الحب سر ابًا و الوطن يبابا }
\end{aligned}
$$

$$
\text { و الحضور غيابا..." ( ( ) . }
$$

$$
\text { فإنِي قد نجوت من الوباء(ro) }
$$

ويستخدم حسن طلب شكلًا جديدًا، يعتمد فيه على تناوب الثكل العَمُوديّ و الثكل المثلنيّ محاولًا أن يبني نصنَّا مختلفًا،

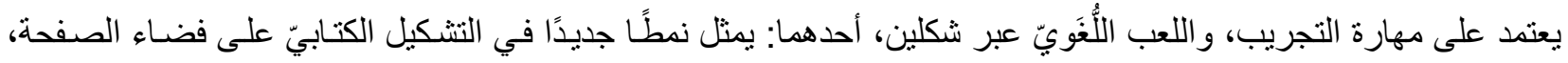

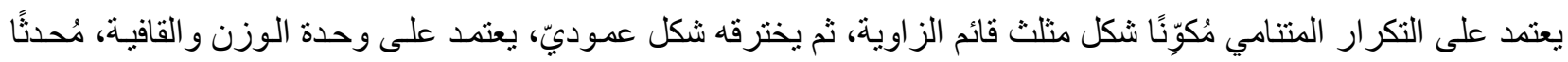
بذلك أمام القارئ فرضية الالتفات البَصَريّ وحركية الِِنْيَة النَّيَّبَّة.

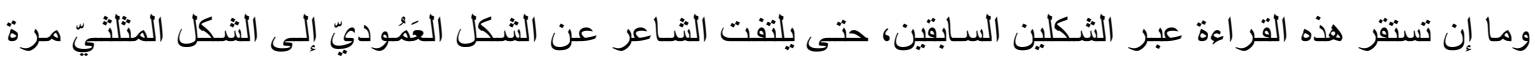
أخرى، ولكن في هذه المرة اعتمد الثـاعر في تثكيل الثنكل المثلثيّ على طريقة مختلفة، تؤدي إلى الإدهاش و إلى الالتفات

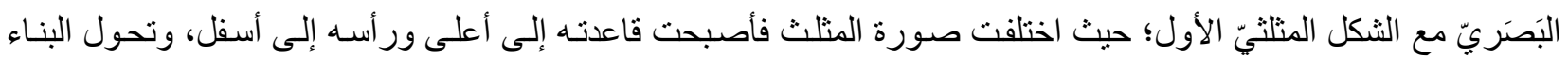

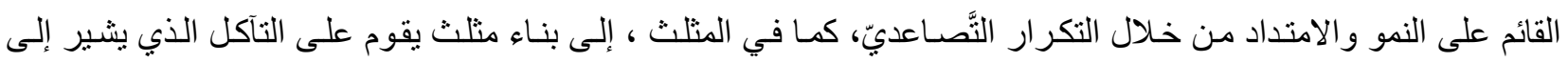
التردِّي و الانهيار وتآكل الو اقع: 


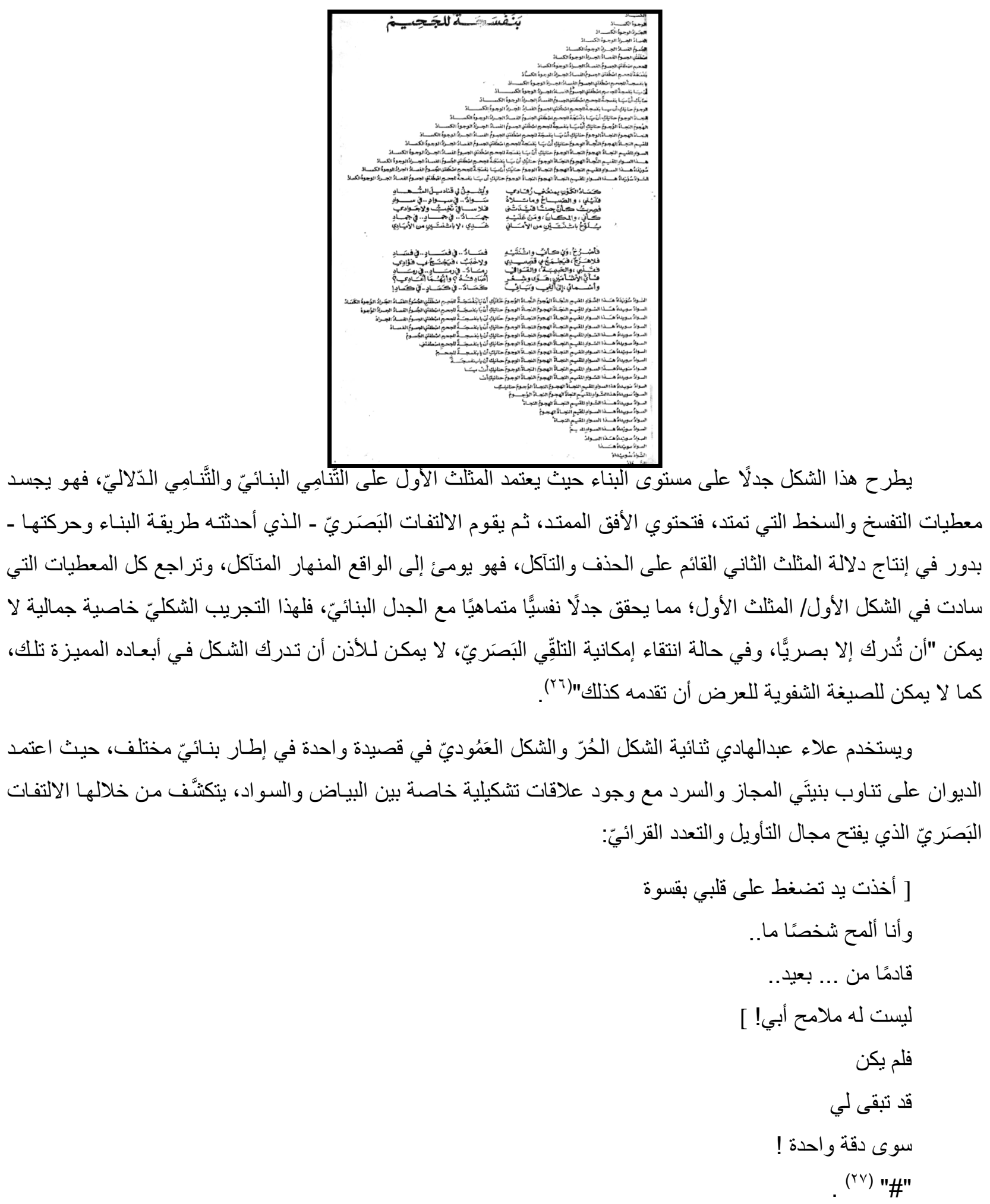

يلتفت القارئ بصريًّا عن الثكل الذي طرحته هذه الصفحة ـ و التي تؤكد مضمون التغيير و التحول، و الانزياح الدّلاليّ؛

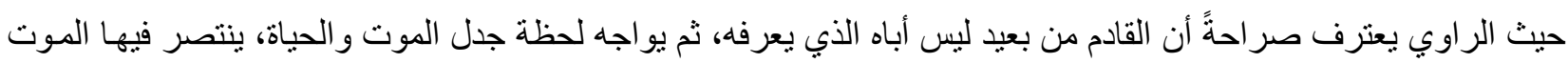

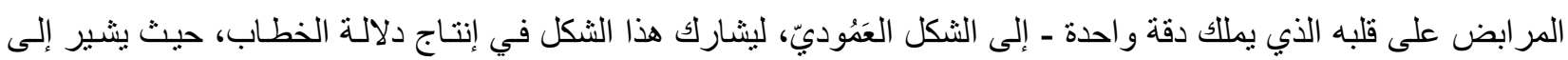
الوحدة و التماهي و النظام عبر وحدة الوزن والقافية والموضوع، وتتصبُّ عين القارئ على أفق محدد يؤكد حالة التوحُد بين 
الراوي وقرينه من جهة، وبين الثكل العُوُوديّ والموضوع/ الرثاء من جهة أخرى:

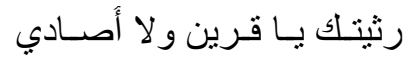

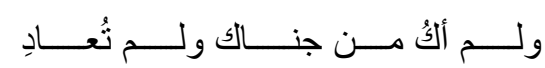

تدثر دفقة الثـهقات صـدري

وكـم خالعــت فـي صــوي رُقــادي

لمعتقل اللســان بغيـر شكــو

طــــواه الوقــت بــأتي فـــي سُـــهادي

فكانـت دعـوتي للقـاك شـوقا

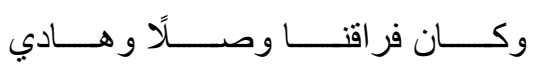

عـلام تحفْنْ رفي رفـات خطـوِ

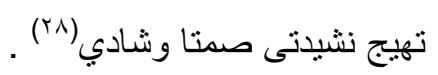

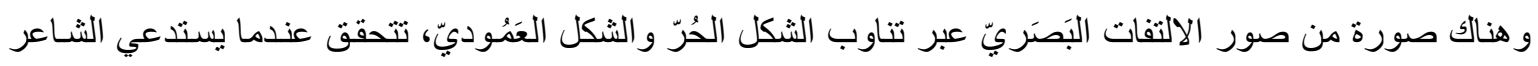

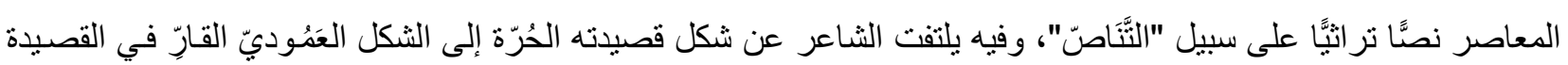

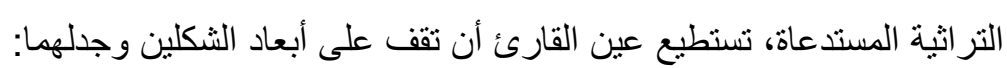

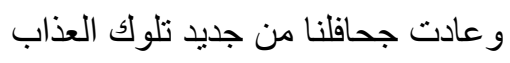

تجـرُ ذيــول المهانــة قانعــة بالإيــاب

يـا دار عبلـةَة (و) حيـث كنـتِ تكلمسي

وصفـــي لنــــا يـــوم اللقـــاء الأســحِ

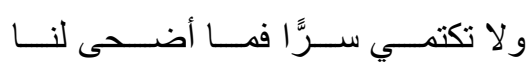




$$
\begin{aligned}
& \text { - يـا دارُ - سـرٌ لـم يُذْع كي تكتمـي }
\end{aligned}
$$

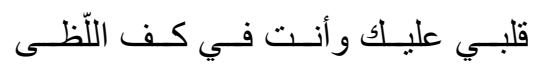

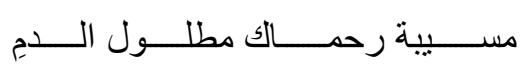

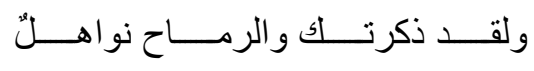

$$
\begin{aligned}
& \text { منّي وبيضُ الهند تطحن أعظمي(Y9). }
\end{aligned}
$$

حقق هذا الالتفات البَصَرَيّ القائم على تناول الثنكل الحُرّ و الثكل التقليديّ رغبة جمالية، تؤكد التواصل على معطيات جمالية

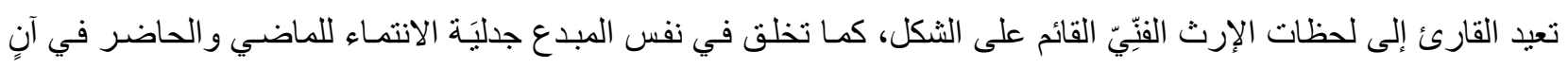
واحد، يستطيع من خلالها أن يكتشف موقعه بالنسبة إلى الآخر / العالم، كما يمكنه مواجهة الآخر بالانتماء إليه ومو اجهته في آنِّ.

\section{الالتفات البصتريّ عبر الشكل الآجَازيّ واليَّزديّي}

عندما كسر الثشاعر المعاصر النََّتق أو النموذج الكلاسيكيّ المنمثل في الثُعر العَمُوديّ وانحاز إلىى الثكل الحُرّ، كان

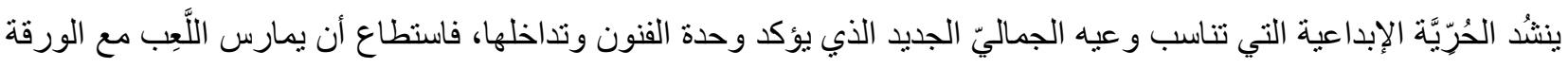

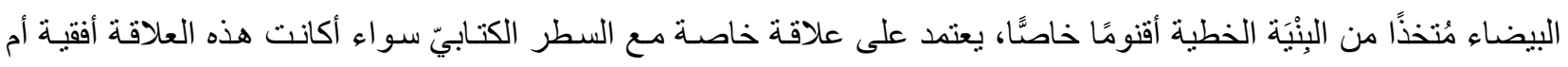

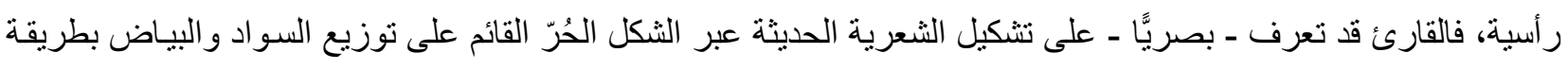

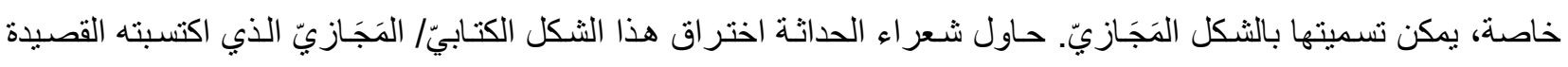

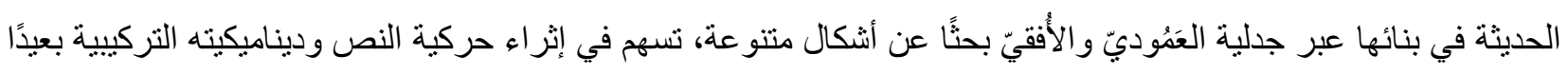

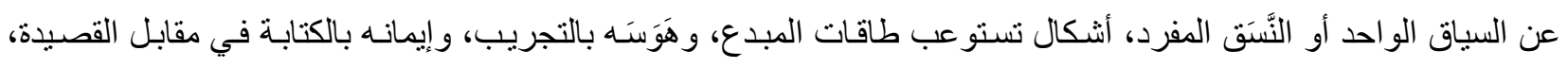

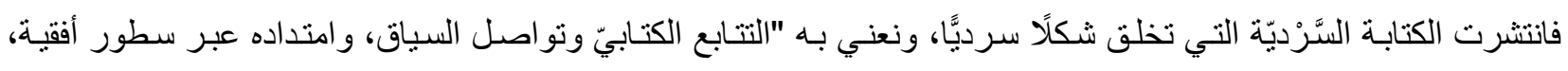

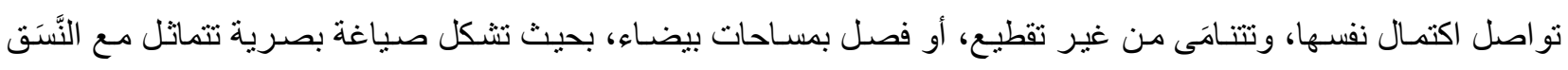

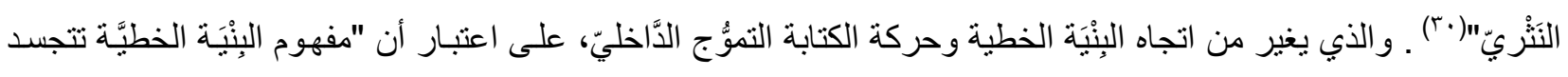

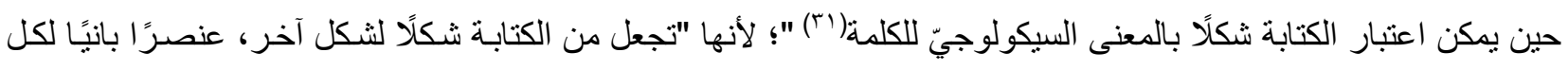

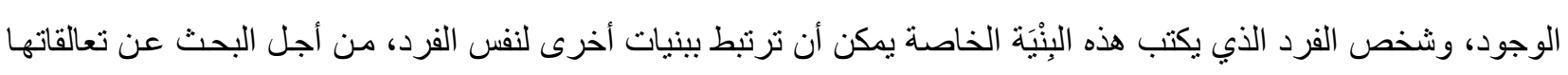
(rr) "[correlations]

تعددت أثنكال الكتابة الجديدة، "فمن الثُعر اء من يستخدم الثكل المَجَازيّ فقط وهو الأغلب و الأعم، أو السَّرديّ فقط" -

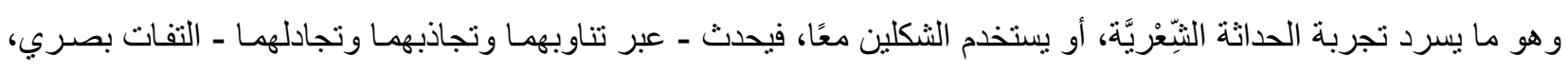

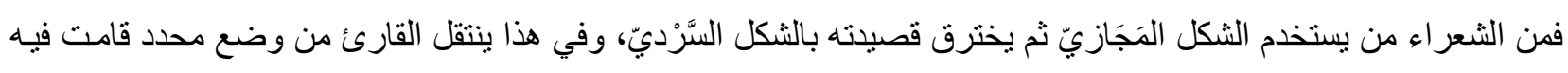

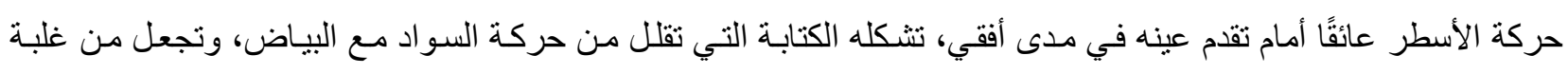

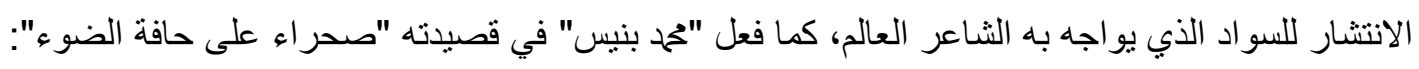




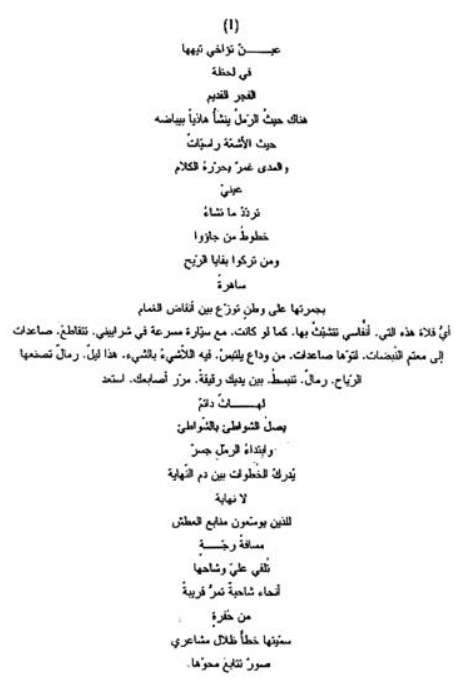

أما رفعت سلام؛ فيستخدم الثكل السَّرّديّ في بناء ديوانه: "إلىى النهار الماضي" يخترقه في بعض المواضع بمقاطع

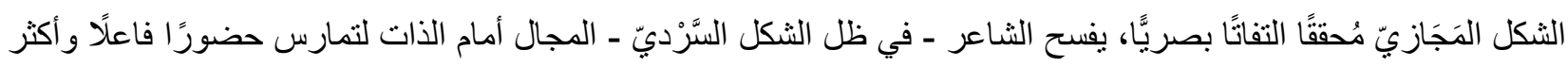

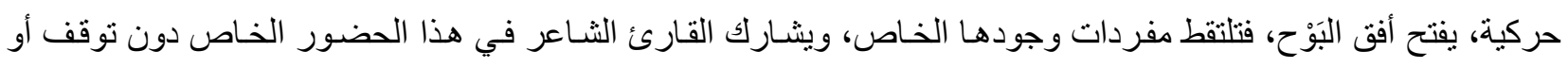

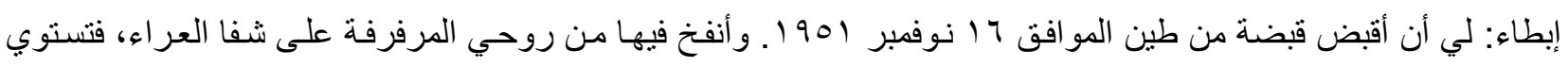

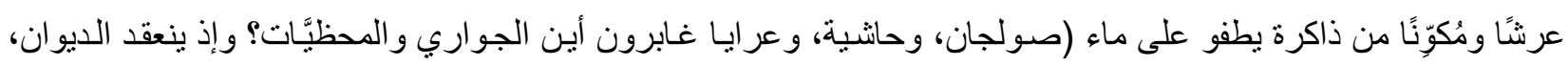

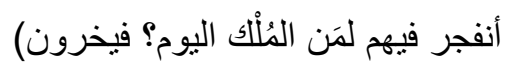
فمن لا يذكر الثدي.

و أمي اختصار سبعة آلاف سنة من أوبئة وطو اعين ومجاعات وفاتحين حقول من عفاريت ليلية تحاذي الذاكرة وبيت

$$
\text { من ريح وشمس جعل قصب يتهادى يقول لي هيت للك ويقول لست سفينة وييكي في حضني وطني }
$$

هذا النمط من الكتابة يفتح مساحة الزمن البنائيّ/ الكتابيّ الخاص بيناء النص في اتجاه أفقيّ، يواجه الثناعر من خلاله

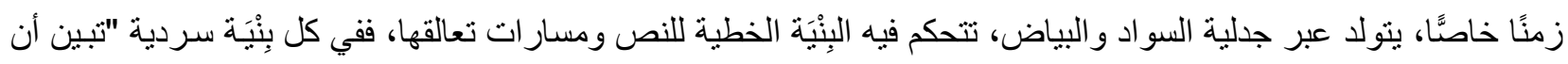

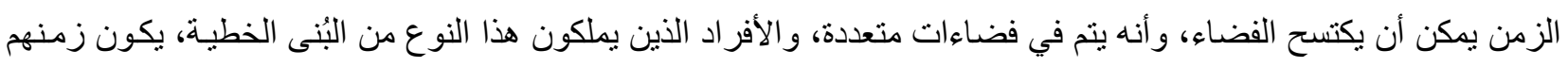

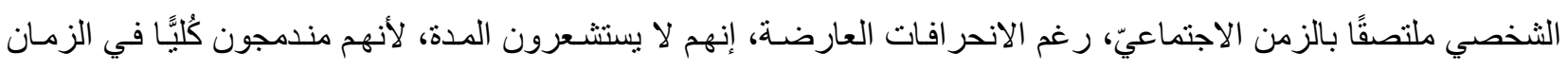

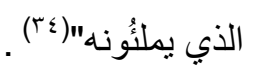

لقد استطاع الثـاعر الجديد - من خلال تناوب الثنكل السَّرْديّ و الثنكل المَجَازيّ ـ أن يكسر الفضـاء الجامد، وأن يضفي

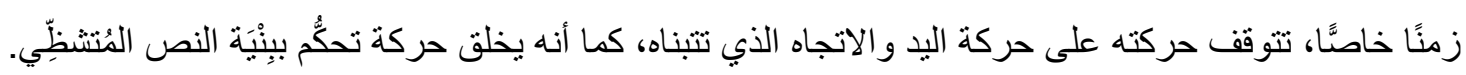

\section{-YYE-}




$$
\begin{aligned}
& \text { (') د. محم نجيب التلاوي: القصيدة التشكيلية، ص:؟ } 9 .
\end{aligned}
$$

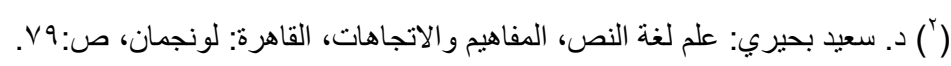

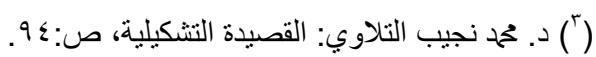

(100)P.Garmir Spatio Lisme Et Poệseệ. Gollimord Paris.P \'.) ( 971

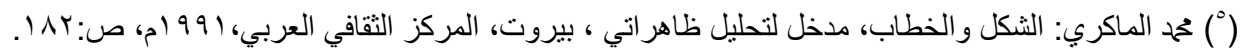

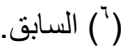

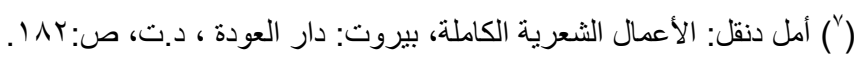

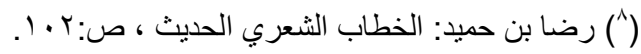

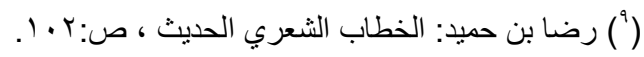

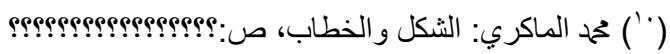

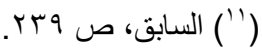

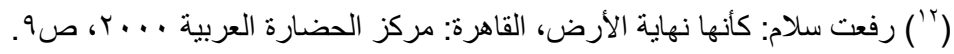

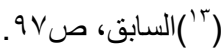

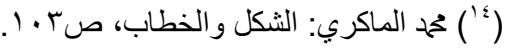

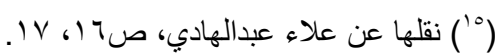

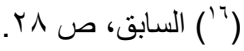

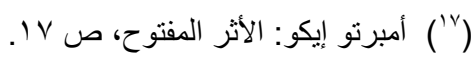

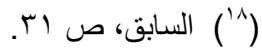

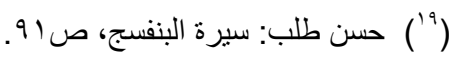

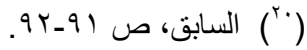

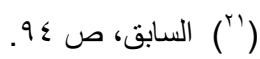

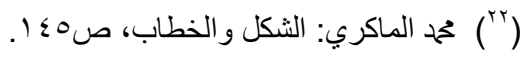

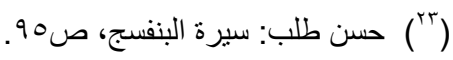

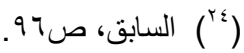

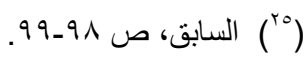

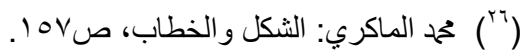

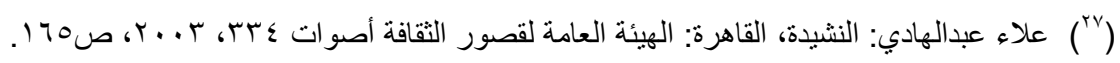

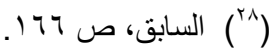

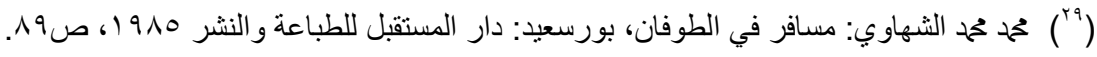

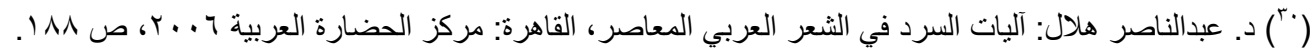

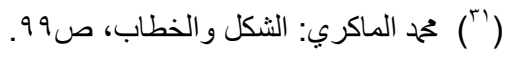

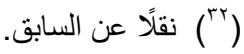

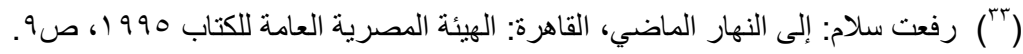

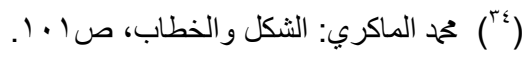

